\title{
Fen Bilimleri Eğitiminde Kavram Öğretimi Yöntemlerine Dayalı Rehber Materyal Tasarımı: Kuvvet ve Hareket
}

\author{
Hüseyin YOLCU $^{1}$, Sevilay KARAMUSTAFAOĞLU ${ }^{2} \&$ Orhan \\ KARAMUSTAFAOĞLU ${ }^{2}$ \\ ${ }^{I}$ Milli Ĕ̆itim Bakanlı̆̆̆, Türkiye \\ ${ }^{2}$ Amasya Üniversitesi, Türkiye
}

Gönderilme Tarihi (Received): 29/07/2021

Düzeltme Tarihi (Revised): 12/10/2021

Kabul Tarihi (Accepted): 16/10/2021

Yaylnlanma Tarihi (Published): 31/12/2021

\begin{abstract}
Özet:
Yürürlükteki Fen Bilimleri Dersi Öğretim Programı'nda pek çok kavram ve bu kavramların birbiriyle olan ilişkisi yer almaktadır. Fen bilimleri ders kitaplarındaki şekilsel ve görsel hatalar, soru anlatımındaki bilimsel hatalar, örnek veya sorulardaki yanllşllklar ile eksiklikler, konular arasındaki bağlantı eksiklikleri vb. durumlar ile öğretmen veya ögrenci kaynaklı bazı durumlar ögrencilerde kavram yanılgılarına sebep olmaktadır. Bu çalışmada "Kuvvet ve Hareket" ünitesine ilişsin ön bilgileri belirleme, özetleme, değerlendirme, kavram yanılgılarının ortaya çıkmasını engelleme veya kavram yanılgısını giderme amacıyla kavram ögretim yöntem ve tekniklerine dayal rehber materyal geliş̧tirilmişstir. Bu tasarım içerisinde bulunan materyaller kavram haritası, kavram ă̆ı, kavram karikatürü, kavram değişim metni, anlam çözümleme tablosu, zihin haritası, bilgi haritası, analoji, V-diyagramı, tanılayıcı dallanmış ağaç, yapılandırılmış grid ve çalışma yaprağıdır. Materyallerin oluşturulma sürecinde uzman görüşünden yararlanılmış ve uzman görüşü doğrultusunda gerekli düzenlemeler yapılmıştır. Son hali verilen kavram ögretim materyalleri kullanılarak, ögretmenlerin "Kuvvet ve Hareket" ünitesi kavramların kazandırırken takip edebilecekleri bir rehber materyal olması amacıyla, bir öğretim tasarımı geliștirilerek, ögretmen ve araştırmacıların kullanımına sunulmuştur.
\end{abstract}

Anahtar Kelimeler: Kavram öğretimi, fen eğitimi, rehber materyal, kuvvet ve hareket.

\section{Guide Material Design Based on Concept Teaching Methods in Science Education: Force and Motion}

\begin{abstract}
:
There are many concepts and the relationship between these concepts in the current Science Curriculum. Formal and visual errors in science textbooks, scientific errors in question expression, inaccuracies or deficiencies in examples or questions, lack of connection between subjects, etc. situations, and some situations originating from teachers or students cause misconceptions in students. In this study, a guide material based on concept teaching methods and techniques has been developed to identify, summarize and evaluate the preliminary information about the "Force and Motion" unit, to prevent the emergence of some misconceptions or to eliminate the misconceptions. The materials included in this design are concept map, concept web, concept cartoon, concept change text, semantic features analysis, mind map, knowledge map, analogy, V-diagram, diagnostic branched tree, structured grid, and worksheet. In the process of creating the materials, expert opinion was used and necessary arrangements were made in line with the expert opinion. Using the finalized concept teaching materials, an instructional design was developed and presented to the use of teachers and researchers to be a guide material that teachers can follow while teaching the concepts of the "Force and Motion" unit.
\end{abstract}

Keywords: Concept teaching, science education, guide material, force and movement. 


\section{GíRIş}

Fen Bilimleri Dersi Öğretim Programı (FBDÖP) incelendiğinde, pek çok kavram ve bu kavramların birbiriyle ilişkilendirilmesinin gerektiği anlaşılmaktadır (Milli Eğitim Bakanlığı [MEB], 2018). Bu kavramların ve kavramlar arası ilişkilerin temel eğitim düzeyinde doğru bir şekilde öğrenilememesi, ilerleyen yıllarda karşılaşılacak yeni kavramların doğru olarak öğrenilmesine engel teşkil edebilir. Bu durum kavramların yanlış bir şekilde öğrenci zihnine kaydedilmesine neden olur. Öğrencilerin zihinlerinde oluşturdukları tanımlar ve anlamaların bilimsel yönden kabul edilmeyen durumlar kavram yanılgıları olarak adlandırılır (İnel Ekici, 2016). Ders kitaplarındaki şekilsel ve görsel hatalar, soru anlatımındaki bilimsel hatalar, örnek veya sorulardaki yanlışlıklar ile eksiklikler, konular arasındaki bağlantı eksiklikleri vb. durumlar ile öğretmen veya öğrenci kaynaklı bazı durumlar öğrencilerde kavram yanılgılarına sebep olmaktadır (Açık, 2015; İnel Ekici, 2016; Liu \& Fang, 2016).

Önceden öğrenilen bilgiler ile yeni bilgilerin birleştirilmesi imkânı öğrencilere ders süreci içinde sağlanmalıdır. Bu durumun sağlanabilmesi dersin yürütülmesinde uygulanacak farklı öğretim teknikleriyle mümkündür (Kinchin, 2000). Buradan hareketle, kavramların doğru bir şekilde öğrenilmesi, mevcut veya olası kavram yanılgılarının giderilmesi amacıyla, kavram, bilgi ve zihin haritaları, kavram karikatürleri, anlam çözümleme tabloları, çalışma yaprakları, tahmin-gözlem-açıklama vb. kavram öğretim yöntem ve tekniklerinden yararlanılabilir. İlgili literatürde kavram öğretimine yönelik çeşitli etkinliklerin ve tasarımların geliştirildiği çalışmalar mevcuttur. Kavramların öğretimi için geliştirilen etkinler incelendiğinde, farklı bilim insanlarının farklı öğretim materyalleri kullanarak öğretim tasarımları geliştirdiği görülmektedir. Köse, Coştu ve Keser (2003) çalışmalarında, Tahmin-Gözlem-Açıklama (TGA) stratejisi konusunda bilgi vermiş ve "Elektromanyetizma, Kaynama ve Fotosentez" konu ve kavramlarına yönelik bir uygulama sunmuştur. Kesercioğlu, Yılmaz, Huyugüzel Çavaş ve Çavaş (2004) çalışmalarında, analojilerin Fen Bilimleri öğretiminde nasıl kullanılabileceği ile ilgili özet bilgiler vermeyi ve fizik, kimya ve biyoloji alanlarıyla ilgili analoji örneklerini sunmayı amaçlamışlardır. Aydın ve Balım (2007), yanlış anlamaların ortadan kaldırılması amacıyla kavramsal değişim etkinliği geliştirmişlerdir. Şaşmaz Ören, Ormancı, Babacan, Koparan ve Çiçek (2011) tarafından yapılmış olan bir çalışmada "madde ve değişim, " temasına yönelik "analoji" ve "araştırmaya dayalı öğrenme yaklaşımı" temelinde bir rehber materyal geliştirilmiştir. Şaşmaz Ören ve Erdem (2014) “Işık” ünitesi konu ve kavramlarının öğretiminde kavram karikatürleriyle desteklenmiş rehber materyal geliştirmişlerdir. Güney ve Özmen (2017) tarafından yapılmış bir çalışmada, bilimsel araştırma yöntemleri dersi için değişken kavramının öğretiminde araştırmacıların geliştirdiği özgün etkinlik örnekleri tanıtılmıştır. Selga (2013) tarafından yapılmış olan bir çalışmada Fen, Teknoloji ve Toplum alanında bir öğretim programı geliştirilmiştir. Pursitasari, Suhardi ve Putikah (2019) yapmış oldukları bir çalışmada öğrencilerin fen bilimlerine ilişkin bilgilerini gerçek yaşamla ilişkilendirmelerine yardımcı olmak ve fen okuryazarlığını teşvik etmek için enerji dönüşümü üzerine eğlenceli fen öğretim materyali geliştirmiştir.

Literatürde materyallerin etkililiğinin araştırıldığ çalışmalar da mevcuttur. Özsevgeç (2006) yapmış olduğu çalışmasında, 5. sınıf "Kuvvet ve Hareket” konu ve kavramlarının öğretiminde öğrenciler tarafından 5E modeline göre geliştirilmiş olan rehber materyalin, akademik başarı ve tutum düzeyleri üzerine olan etkisini incelemiştir. Bakırcı ve Çalık (2013) adaptasyon ve doğal seçilim konuları için hazırlanan rehber materyallerin öğrencilerin sahip olduğu alternatif kavramların giderilmesi üzerindeki etkisini incelemişlerdir. Anıl ve Küçüközer (2015) 
çalışmalarında, yapılandırmacılık temelinde 5E modeline uygun örnek bir öğretim modelini tasarlayıp uygulamışlardır. Er Nas ve Çepni (2016) yapmış oldukları çalışmalarında, "Isının Yayılma Yolları" kavramlarının öğretiminde derinleştirme aşamasına uygun rehber materyaller hazırlamış ve kavramsal anlamalar üzerine olan etkisini araştırmışlardır. Ula ve Mariyani (2021) sorgulamaya dayalı bir anlayışla temel fen kavramlarına ilişkin bir öğretim materyali geliştirmiş ve uygulamıştır. Leuchter, Saalbach ve Hardy (2014) yapmış oldukları bir çalışmada anaokulu çocuklarının, "yüzme ve batma" kavramlarına ilişkin kavramsal değişimi teşvik etmesi beklenen sıralı ve probleme dayalı görevlere sahip bir öğretim tasarımı geliştirmiş ve bu tasarımın uygulamasını gerçekleştirmiştir. Purwitaningrum ve Prahmana (2021) tarafından yapılmış bir çalışmada matematiksel mantıksal düşünmeyi geliştirmeye odaklı çalışma yaprakları geliştirilmiş ve uygulanmıştır. Ekantini ve Wilujeng (2018) tarafından yapılmış olan bir çalışmada çevresel sürdürülebilir kalkınma eğitimine dayalı olarak öğrenciler için fen çalışma yaprağı geliştirilmiş ve uygulanmıştır.

Bunun yanında literatürde 6. sınıf "Kuvvet ve Hareket" ünitesine yönelik yanlış anlamaların araştırılması veya giderilmesine yönelik çalışmalar da vardır. Yılmazlar, Takunyacı ve Günaydın (2014) çalışmalarında kavram yanılgılarını araştırmış ve 6. sınıf öğrencilerinin hem kuvvet hem de sürat konularında kavram yanılgılarına sahip oldukları sonucuna ulaşmışlardır. Nuhoğlu (2008) çalışmasında ilköğretim öğrencilerinin, Zeybek (2007) yapmış olduğu bir çalışmasında sınıf öğretmeni adaylarının kuvvet ve hareket konusunda kavram yanılgılarına sahip olduğu sonucuna varmıştır.

$\mathrm{Bu}$ çalışmalar değerlendirildiğinde, kavram öğretiminde kavram değişim metinleri, analoji (benzeşim), kavram haritaları, kavram karikatürleri, zihin haritaları vb. yöntem ve tekniklerin öğretmenlere rehber materyal olarak sunulduğu görülmektedir. Ancak bu çalışmalar genellikle tek bir yöntem veya teknik üzerinden yürütülmüştür. Ayrıca alanyazında 6. sınıf "Kuvvet ve Hareket" ünitesine yönelik hazırlanmış rehber materyal türünde bir çalışmaya rastlanmamıştır. Bunun yanında "Kuvvet ve Hareket" ünitesindeki kavramlarla ilgili olarak "Hareket yoksa kuvvet de yoktur, kuvvet uygulanmıyorsa hareket de olmaz, kuvvet uygulanmışsa hareket de oluşur, sabit süratli hareket için sürekli kuvvet uygulanmalıdır, cisme sadece bir kuvvet etki eder, hareket halinde olan bir cisim dengede olamaz, kuvvet ve hareket aynı yönde olmak zorundadır, kuvvetin yönü yoktur, sürat bir kuvvettir." vb. kavram yanılgıları bulunması (Bani Salameh, 2017; Günaydın, 2010; Liu \& Fang, 2016; Özsevgeç, Çepni ve Bayri, 2007; Sadanand \& Kess, 1990; Şimşek, Yurtcan \& Oktay, 2019); günlük yaşamla oldukça ilişkili olması gibi nedenlerden dolayı, ilgili ünite konu ve kavramlarının öğretiminde, dersin farklı bölümlerinde ve farklı amaçlar için kavram öğretim yöntem, teknik ve tasarımları içeren bir rehber materyal öğretmenlerin ve araştırmacıların kullanımı için geliştirilmiştir. Bu bağlamda 6. sınıf "Kuvvet ve Hareket" ünitesine yönelik birçok kavram öğretimi yöntem ve tekniğinin öğretmenlere rehber materyal olarak sunulmasının amaçlandığ 1 bu çalışmanın alan yazındaki bu eksikliğin giderilmesine kaktı sağlayacağı düşünülmektedir.

\section{YÖNTEM}

Bu çalışmada öğretim sürecinin farklı aşamalarında kullanılabilecek kavram öğretim yöntem ve teknikleri kullanılarak 6. sınıf "Kuvvet ve Hareket" ünitesine yönelik bir rehber materyal geliştirilmiştir. "Kuvvet ve Hareket" ünitesi kapsamında "Bileşke Kuvvet" ve "Sabit Süratli Hareket" konuları bulunmaktadır. Rehber materyal FBDÖP'de yer alan konu kazanımları doğrultusunda öğretmenin ders sürecinde takip edebileceği bir dokuman olarak tasarlanmıştır. Rehber materyal oluşturulurken öncelikli olarak alanyazında kavram öğretim 
yöntem ve teknikleri, öğretim tasarımlarıyla ilgili çalışmalar değerlendirilmiştir. Belirlenen ünite ve konu kapsamında öğretim sürecinde farklı amaçlarla (ön bilgileri belirleme, özetleme, değerlendirme, bazı kavram yanılgılarının ortaya çıkmasını engelleme veya kavram yanılgısını giderme) kullanılmasına yönelik kavram haritası, zihin haritası, kavram ağı, yapılandırılmış grid, tanılayıcı dallanmış ağaç, anlam çözümleme tablosu vb. gibi çeşitli materyaller hazırlanmıştır. Materyallerin oluşturulma sürecinde alan eğitimi uzmanı iki öğretim üyesinin görüşleri alınmış olup bu görüşler doğrultusunda gerekli düzenlemeler yapılmıştır. Son hali verilen kavram öğretim materyalleri, yöntem ve teknikler kullanılarak, öğretmenlerin "Kuvvet ve Hareket" ünitesindeki kazanımları kazandırmada takip edebilecekleri bir rehber materyal olması amacıyla, bir öğretim tasarımı geliştirilmiştir.

\section{BULGULAR}

$\mathrm{Bu}$ bölümde "Kuvvet ve Hareket" ünitesine ilişkin kavram öğretim yöntem ve tekniklerini içeren, öğretmenlere rehber mahiyetinde hazırlanan örnek bir öğretim tasarımına yer verilmiştir. Söz konusu üniteye ait kazanımlar için ayrılan sürenin 14 ders saati olduğu FBDÖP'te belirtilmiştir. Ayrıca Türkiye'de 6. sınıf Fen Bilimleri dersi haftada 4 saattir. Bu bağlamda dört ders saatine göre tasarlanmış iki, altı ders saatine göre tasarlanmış bir olmak üzere toplam üç adet öğretim tasarımı geliştirilmiştir. Öğretim tasarımlarının haftalık olarak düzenlenmesinin gerekçesi, öğretmenin 40 dakika ile sınırlandırıldığını düşünmesinin önüne geçmek ve öğretmenin öğrenci, sınıf, zaman gibi değişkenleri göz önünde bulundurarak 40 dakikalık ders sürecini kendine göre planlamasına olanak tanımaktır. Hazırlanan rehber öğretim tasarımları aşağıda sunulmuştur.

Tablo 1. Öğretim Tasarımı - 1

\begin{tabular}{|c|c|}
\hline Dersin adı & Fen Bilimleri \\
\hline Sinıf & 6 \\
\hline Ünitenin Adı/No & Kuvvet ve Hareket \\
\hline Konu & F.6.3.1. Bileşke Kuvvet \\
\hline Önerilen Süre & 4 Ders Saati \\
\hline Öğrenci Kazanımları & $\begin{array}{l}\text { "F.6.3.1.1. Bir cisme etki eden kuvvetin yönünü, doğrultusunu ve büyüklüğ̈̈nü } \\
\text { çizerek gösterir." } \\
\text { "F.6.3.1.2. Bir cisme etki eden birden fazla kuvveti deneyerek gözlemler." }\end{array}$ \\
\hline $\begin{array}{l}\text { Ünite Kavramları ve } \\
\text { Sembolleri/Davranış } \\
\text { Örüntüsü }\end{array}$ & $\begin{array}{l}\text { "Kuvvetin özellikleri (yön, doğrultu, büyüklük), bileşke kuvvet (net kuvvet), aynı } \\
\text { doğrultulu ve aynı yönlü kuvvetlerde bileşke kuvvet, aynı doğrultulu ve zit yönlü } \\
\text { kuvvetlerde bileşke kuvvet, dengelenmiş ve dengelenmemiş kuvvetler” }\end{array}$ \\
\hline Açıklamalar & $\begin{array}{l}\text { "Aynı doğrultudaki kuvvetlerin bileşkesi üzerinde durulur.” "Doğrultuları } \\
\text { farklı kuvvetlerin bileşkesine girilmez." }\end{array}$ \\
\hline \multicolumn{2}{|c|}{$\begin{array}{l}\text { BİLEŞKE KUVVET } \\
\text { Dersin başında, öğrencilerin daha önceki yıllarda kuvvetle ilgili öğrendiği bilgileri ortaya çıkarmak } \\
\text { amacıyla, beyin fırtınası tekniği kullanılarak öğrencilerle birlikte aşağıda bir örneği verilen zihin haritası } \\
\text { oluşturulur. }\end{array}$} \\
\hline
\end{tabular}




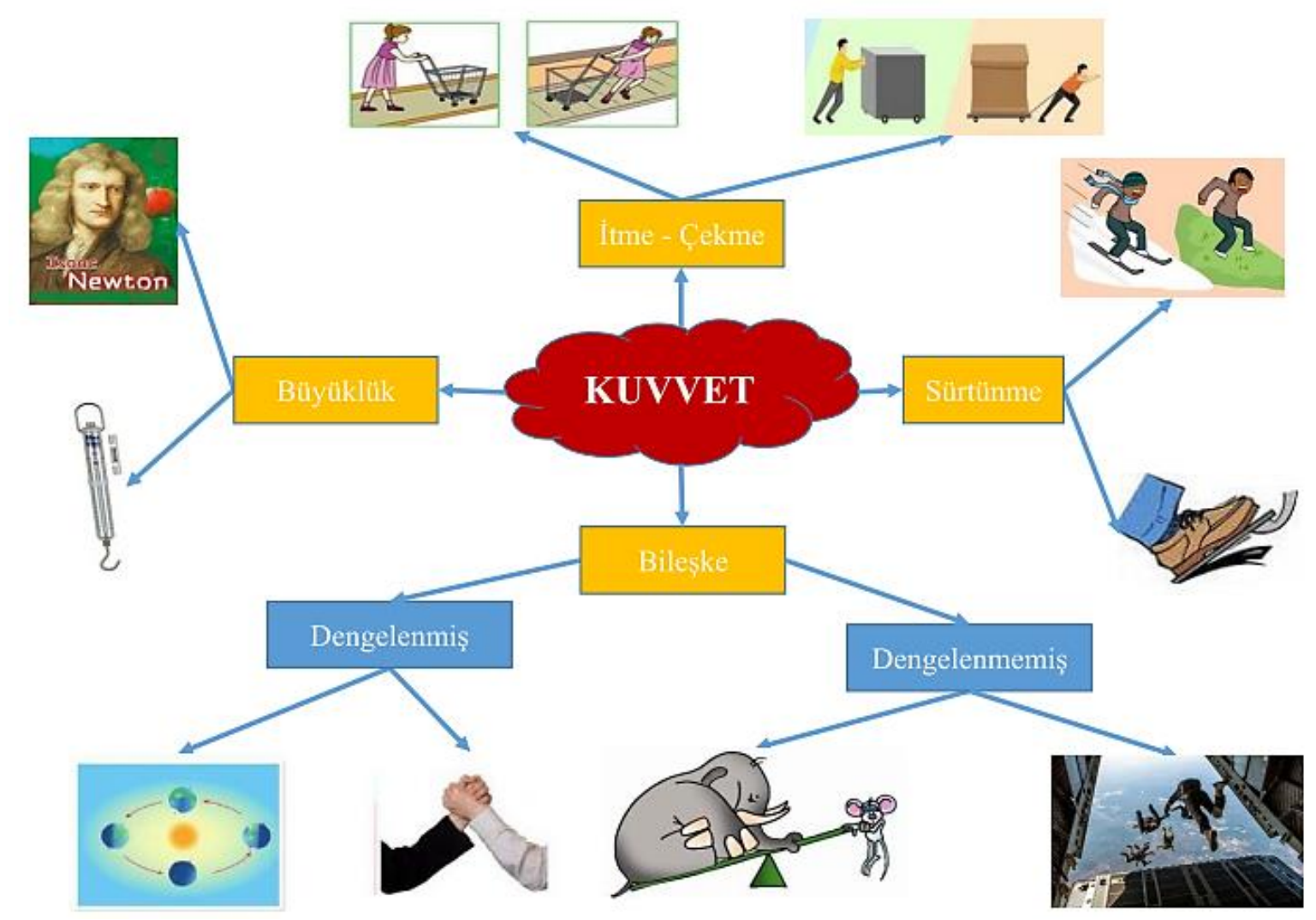

Zihin haritasıyla ön bilgileri yoklandıktan sonra, aşağıda yer alan kavram değişim metni kullanılarak öğrencilerdeki olası kavram yanılgısı giderilir.

Her Kuvvet Sonucunda Hareket Olmaz ki!

Bazı öğrenciler uygulanan her kuvvetin sonucunda bir hareket gerçekleşeceğini düşünür. Bu bir kavram yanılgısıdır. Böyle düşünmelerinin sebebi, sırayı ittiklerinde sıranın ilerlemesi, topa vurduklarında topun hareket etmesi, çiviye vurduklarında çivinin tahtaya girmesi, pet şişeyi sıktıklarında şişenin büzüşmesi gibi olaylardır. Ancak uygulanan kuvvetin hareket etkisi göstermesi, uyguladığımız kuvvetin yönüne bağlı olarak, kuvvetin büyüklüğüne, yüzeyin sürtünme kuvvetinin büyüklüğüne göre değişir. Bu bağlamda kuvvet uyguladığımız her cisim hareket etmek zorunda değildir. Örneğin binanın duvarını tüm gücümüzle itsek de bina hareket etmeyecektir ya da duvarda asılı duran tabloya yer çekimi kuvveti etki etmesine rağmen hareket etmemektedir.

Ayrıca kuvvetin cisimler üzerinde şekil değiştirici etkisi de vardır. Örneğin, yaya kuvvet uygulayarak yayın sıkışması, paket lastiğine kuvvet uygulayarak lastiğin esnemesi, metal bir tele kuvvet uygulayarak telin bükülmesi mümkündür.

Sonuç olarak cisme etki eden her kuvvet cismi hareket ettirmek zorunda değildir. Yani her kuvvet sonucunda hareket gözlenmez.

Bu aşamadan sonra öğretmen kuvvet ve kuvvetle ilgili kavramları Bruner’in kavram öğretimi dikkate alınarak, bilimsel olarak açıklar ve günlük hayattan örnekler verir.

Duran bir cismi hareket ettirebilen, hareket eden cismi yavaşlatan veya durduran, cisimlerin yönünü veya şeklini değiştirebilen etkiler kuvvet olarak tanımlanmaktadır.

- Kuvvet ok işareti ile gösterilir.

- Kuvvetin simgesi "F" harfidir.

Kuvvetin sahip olduğu üç özellik bulunmaktadır;

1-Yönü: Cismin kuvvet etkisiyle hareket ettiği yönü tanımlar. Doğu yönü, batı yönü, kuzey yönü, güney yönü gibi.

2-Doğrultusu: Cismin kuvvet etkisiyle hareket ettiği doğrultudur. Bir doğru boyunca yapılan hareket olarak düşünülebilir. Kuvvetin çift taraflı yön ile ifade edilmesidir. Kuzey-güney doğrultusu, doğu-batı doğrultusu gibi. 3-Şiddeti (Büyüklüğü): Kuvvetin dinamometreyle ölçülmesi sonucunda elde edilen değeridir.

Daha sonra kuvvetin ölçümüyle ilgili kavram yanılgılarını ortadan kaldırmak için aşağıdaki kavram değişim metni kullanılır. 


\section{Kuvveti Ölçebilir miyiz?}

Öğrencilerden bazıları kuvvetin ölçülebileceğini düşünür. Bu hatalı bir düşüncedir. Böyle düşünmelerinin sebepleri ders veya kaynak kitaplarda geçen ya da öğretmenlerin konuyu anlatırken kullandıkları "kuvveti ölçmek, eşit kuvvetler, kuvvetlerin toplamı veya fark1, bileşke kuvveti hesaplayalım" vb. ifadeler olabilir. Oysaki 6. sınıf düzeyinde kuvvet konusunda kuvvetin büyüklüğü (şiddeti), yönü ve doğrultusu olduğu anlatılmaktadır. $\mathrm{Bu}$ durumda dinamometre kullanarak kuvvetin yönünü veya doğrultusunu ölçemeyiz. Dolayısıyla da kuvveti ölçemeyiz. Diğer bir deyişle dinamometre ile kuvvetin büyüklüğünü ölçebiliriz.

Kavram değişim metni kullanıldıktan sonra aşağıdaki kavram karikatürü kullanılır ve öğrencilerin fikirleri alınarak, kavramalarla ilgili tartışılır ve sonuçlandırılır.

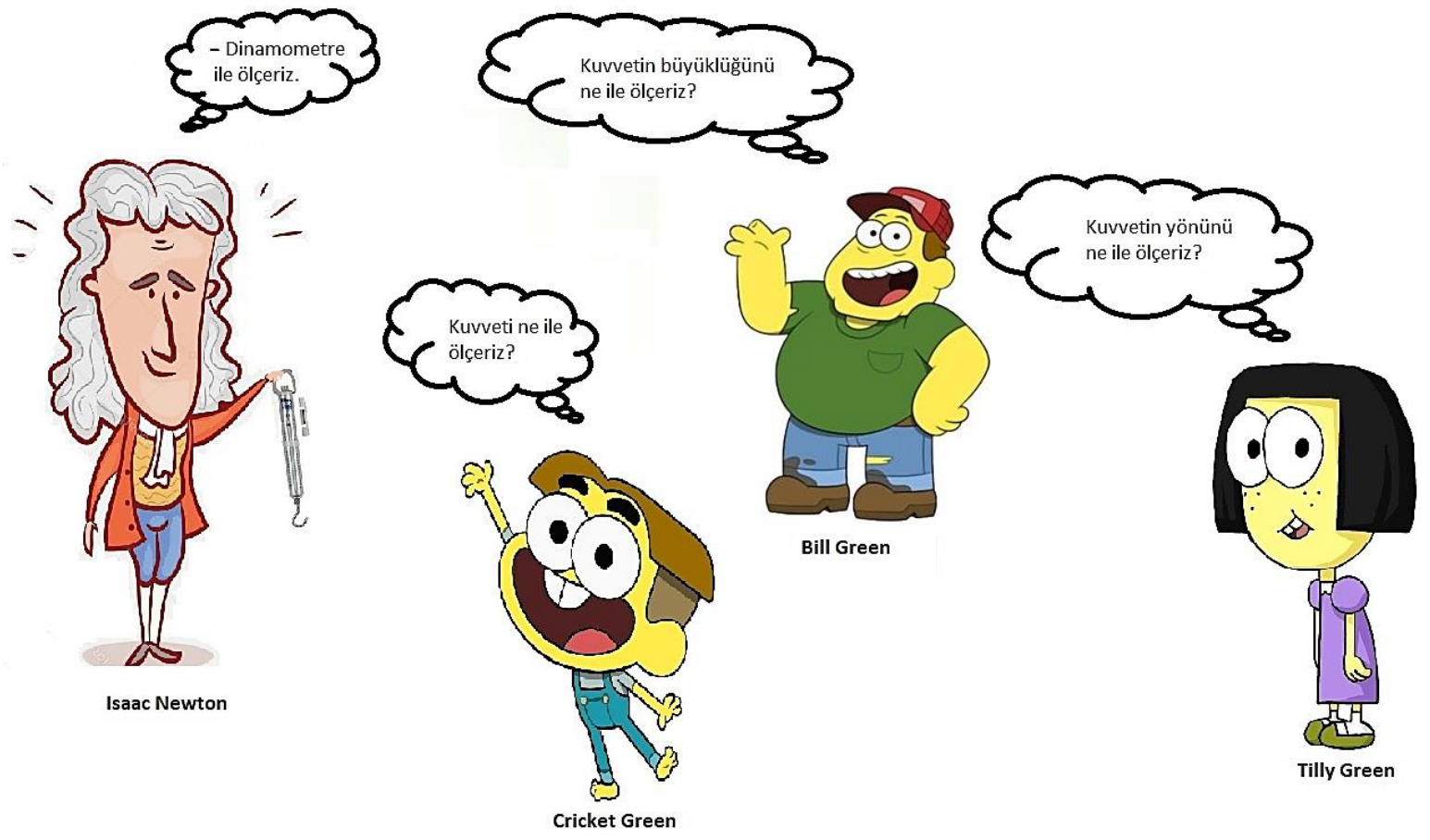

Sizce Newton Öğretmen kimin sorusuna cevap vermiştir? Neden böyle düşünüyorsunuz?

Kavram karikatüründe öğrencilerden istenilenler ve neden böyle düşündüklerini açıklamaları doğrultusunda, diğer konuya geçilir.

Bazı durumlarda cisimler üzerine birden fazla kuvvet uygulanır. Bu durumda bu kuvvetlerin tamamının oluşturduğu etkiyi tek başına yapabilen kuvvet bileşke kuvvet ya da net kuvvet olarak tanımlanmaktadır.

Bileşke kuvvetin simgesi, "R" harfidir.

Bileşke kuvveti hesaplamak için iki yöntemden yararlanılır.

\section{1-Aynı Yönlü Kuvvetlerin Bileşkesi}

*Cisimler üzerine etki eden kuvvetlerin yönleri aynı ise kuvvetlerin büyüklükleri birbiri ile toplanır böylece bileşke kuvvetin büyüklüğü elde edilir. Bileşke kuvvetin yönü, kuvvetlerin yönüyle aynıdır.

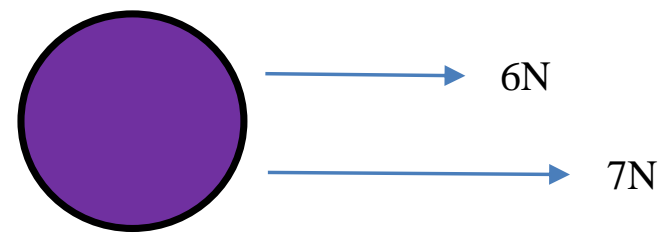

Bileşke kuvvetin büyüklüğü $(R)=6 N+7 N=13 N$ ve bileşke kuvvet doğu yönündedir.

\section{2-Zıt Yönlü Kuvvetlerin Bileşkesi}

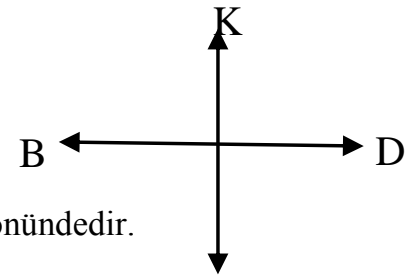

$\mathrm{G}$

Cisim üzerine etki eden kuvvetler zıt yönlü ise kuvvetlerin büyüklüklerinin matematiksel farkları alınır, elde edilen değer bileşke kuvvetinin büyüklüğüdür. Bileşke kuvvet, büyük kuvvetin yönüyle aynıdır.

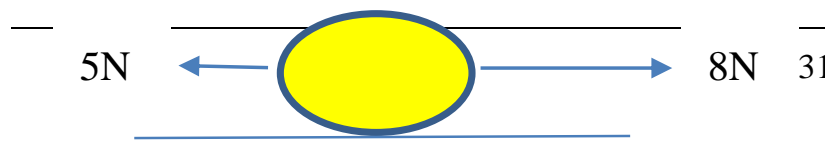


Bileşke kuvvetin büyüklüğü $(\mathrm{R})=8 \mathrm{~N}-5 \mathrm{~N}=3 \mathrm{~N}$ ve bileşke kuvvet doğu yönündedir.

Bu bölümde konu sonu değerlendirme amacıyla aşağıda yer alan öğretim materyalleri kullanılır. Anlam Çözümleme Tablosu-Kuvvetin Özellikleri

\begin{tabular}{|c|c|c|c|}
\hline 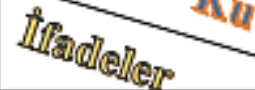 & I)0อั่ulus & Yinii & Biiyukliigii \\
\hline 10 Newton & & & \\
\hline Samsun'a & & & \\
\hline Dinamometre & & & \\
\hline Yatay & & & \\
\hline 6 Newton & & & \\
\hline Amasya'dan Sivas'a & & & \\
\hline Batıya & & & \\
\hline Aşağıdan yukarıya & & & \\
\hline
\end{tabular}

Daha sonra aşağıda yer alan çalışma yaprağı öğrencilere dağıtılarak öğrenci merkezli çalışmalar yaptırılır. 


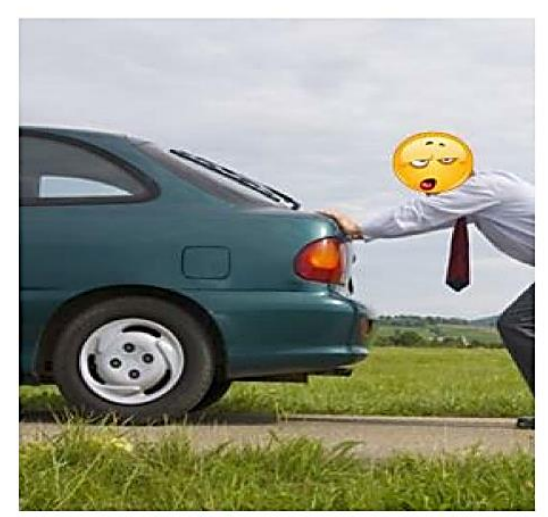

\section{Birlikten Kuvvet Doğar}

Mustafa, başından geçen bir olayı günlüğüne şu şekilde not etmiş. -Bir gün babamla birlikte arabada seyahat ederken babam birden durdu. Merak edip sordum "Ne oldu, niye durduk?" diye. Babam da "Yolda duran bir araba var, muhtemelen bozulmuş." dedi. Arabadan indik ve baktık ki araç sahibi tek başına arabayı itmeye çalışıyor, ancak araba çok yavaş hareket ediyor. Bu durum adamı yormuş olmalı. Babam "Hadi oğlum şu arabaya bir el atalım da hep beraber yolun geniş bir yerine alalım." dedi. Babama, "Adam zaten arabayı itiyor, hep beraber itince ne değişecek?" diye sordum. Babam "Öyle deme oğlum, ne demiş atalarımız! Birlikten kuvvet doğar." dedi. Benim kafam karıştı ama merak etmeye de başladım. Hep beraber itelim, bakalım ne değişecek?

Mustafa'nın merağını gidermesine ve sorusuna cevap bulmasına yardımcı olalım.

Araç - Gereçler

* Dinamometre

* Deney arabas 1

* Ağırlıklar

\section{Deneyin Uygulanması (Grup deneyi)}

* Deney arabasına ağırlıkları yerleştiriniz.

* Dinamometreyi arabanın bir noktasına sabitleyiniz (Şekil 1).

* Dinamometre ile arabayı çekip hareket etmesini sağlayınız ve dinamometrede okunan değeri not ediniz

* İki dinamometreyi arabanın aynı noktasına sabitleyiniz (Şekil 2).

* Dinamometreler ile arabayı çekip hareket etmesini sağlayınız ve dinamometrelerde okunan değeri not ediniz.

* Her iki ölçüm sonuclarını karşılaştırınız.
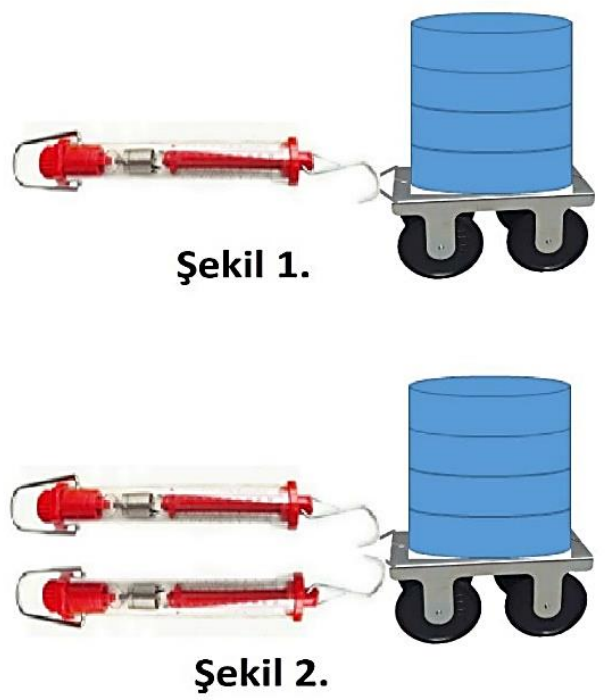

Aşağıdaki soruları cevaplandıralım.

1. Arabaya eklenen ağırlıkları değiştirmeniz durumunda

dinamometrede okunan değer nasıl değişir?

2. Birinci ölçümde dinamometrede okunan değer ile ikinci ölçüm değeri arasında nasıl bir ilişki vardır?

3. Dinamometreleri karşılıklı noktalardan arabaya sabitleyip zıt yönlerde çekmeniz durumunda deney sonucunda nasıl değişiklikler olurdu

Çalışma yapră̆ı uygulatıldıktan sonra öğrencilerden aynı etkinliğin V-diyagramını evde hazırlamaları istenir. Aşağıda örnek bir V-diyagramı yer almaktadır. 
Teorik Kısım

Kuvvet: Bir cisme

uygulandığında, cismin hareket durumunu, hareket yönünü ve şeklini değiştirebilen etkiler, kuvvet olarak tanımlanabilir. Kuvvetin yönü, doğrultusu ve büyüklüğü vardır.

Bileşke Kuvvet: Bir cisme etki eden kuvvetlerin tamamının oluşturduğu etkiyi tek başına oluşturan kuvvet, bileşke kuvvet olarak tanımlanır.

Dinamometre: Bir cisme etki eden kuvvetin büyüklüğünü ölçmeye yarayan alettir.

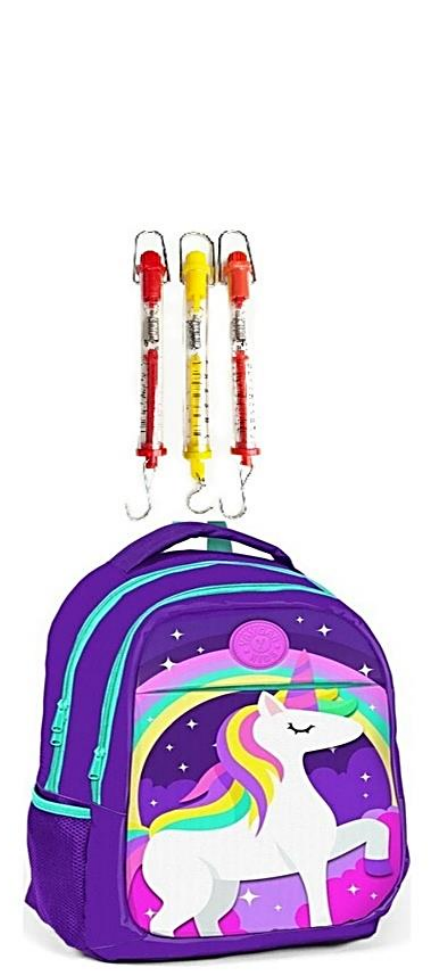

Deneysel Kısım

Hipotez: Birden fazla kuvvet uygulayarak hareket ettirilebilen bir cisim, tek kuvvet ile de hareket ettirilebilir.

Bağımsız değişken: Uygulanan kuvvet sayısı

Bağımlı değişken: Cismin hareket durumu

Kontrol değișkeni: Cismin ağırlığı

* 3 adet dinamotre

* 10-15 adet kitap-defter

* 1 adet okul çantası

\section{Yöntem}

* Araştırma ve sorgulamaya dayalı öğretim

* Tümevarım laboratuvar yaklaşımı

* Açık uçlu deney ve gözlem tekniği

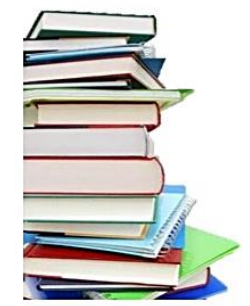

\section{Deneyin Yapılışı}

* Kitaplar ve defterler okul çantasına doldurulur.

* İlk olarak, 3 dinamometre kullanılarak çanta kaldırılır ve dinamometrede okunan değer 1.ölçüm olarak kaydedilir.

* Sonrasinda, 2 dinamometre kullanılarak çanta kaldırılır ve dinamometrede okunan değer 2.ölçüm olarak kaydedilir.

* Son olarak 1 dinamometre kullanılarak çanta kaldırılır ve dinamometrede okunan değer 3.ölçüm olarak kaydedilir.

\section{Deneyin Sonucu}

* Bir kuvvek kullarak hareket ettirebildiğimiz bir cismi, farklı sayıda kuvvetler uygulayarak da hareket ettirebildiğimizi gözlemledik.

* Bir cismi hareket ettirebilmek için uygulamamız gereken kuvvet değeri, uygulayacağımız kuvvet sayısına bağlı değildir.

\section{Değerlendirme}

* Bir cismi daha düşük şiddette kuvvetler uygulayarak hareket ettirmek mümkündür 
Tablo 2. Öğretim Tasarımı - 2

\begin{tabular}{ll}
\hline Dersin adı & Fen Bilimleri \\
Sınıf & 6 \\
Ünitenin Adı/No & Kuvvet ve Hareket \\
Konu & F.6.3.1. Bileşke Kuvvet \\
Önerilen Süre & 4 Ders Saati \\
Öğrenci Kazanımları & "F.6.3.1.3. Dengelenmiş ve dengelenmemişs kuvvetleri, cisimlerin hareket \\
& $\begin{array}{l}\text { durumlarını gözlemleyerek karşılaştırır." } \\
\text { Ünite Kuvvetin özellikleri (yön, doğrultu, büyüklük), bileşke kuvvet (net kuvvet), aynı } \\
\text { Sembolleri/Davranış }\end{array} \quad$ ve $\begin{array}{l}\text { doğrultulu ve aynı yönlü kuvvetlerde bileşke kuvvet, aynı doğrultulu ve zlt yönlü } \\
\text { Örüntüsü }\end{array}$ \\
kuvvetlerde bileşke kuvvet, dengelenmiş ve dengelenmemiş kuvvetler"
\end{tabular}

Açıklamalar

“Aynı doğrultudaki kuvvetlerin bileşkesi üzerinde durulur." "Doğrultuları farklı kuvvetlerin bileşkesine girilmez.”

Bu bölümde derse başlarken aşağıdaki kavram ağı oluşturularak hem önceki bilgiler hatırlatılır hem de bu derste öğrenilecek kavramlar hakkında bilgi verilir.

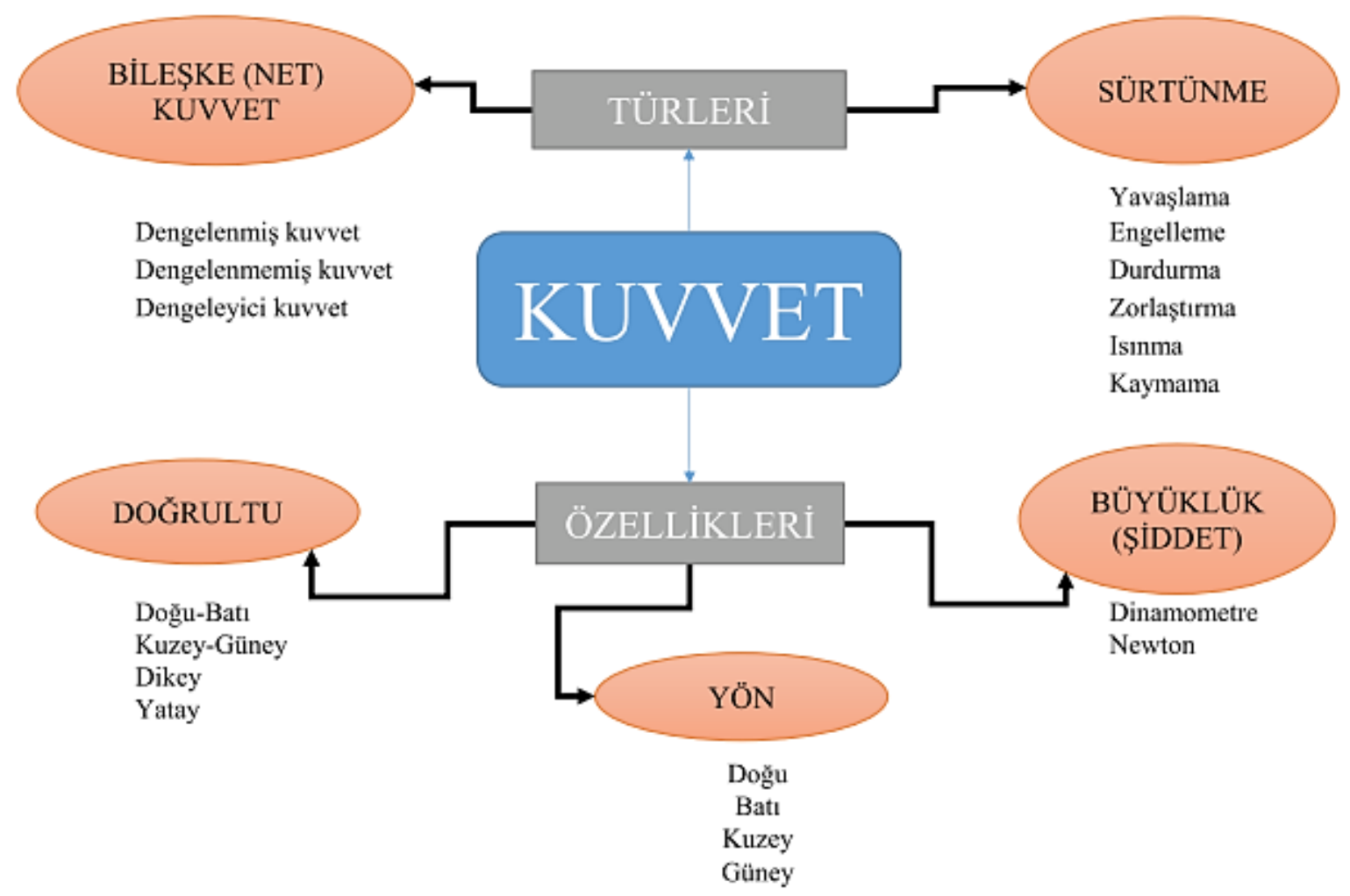

\section{Dengelenmiş Kuvvet}

Dengelenmiş ve Dengelenmemiş Kuvvetler

Bir cisme etki eden bileşke kuvvetin büyüklüğü sıfır ise cisim dengelenmiş kuvvetlerin etkisi altındadır. *Dengelenmiş kuvvetlerin etkisinde olan cisimler ilk hareketini sürdürür. Yani cisim bileşke kuvvet etki etmeden önce duruyorsa, durmaya devam eder; sabit süratli hareket yapıyorsa, sabit süratle hareket etmeye devam eder. ** Dengelenmiş kuvvetlerin etkisinde olan cisimler için bileşke kuvvetin büyüklüğü daima sıfır (0)'dır.

Bu aşamada aşağıda yer alan TGA etkinliği uygulanır. 


\section{TAHMIN:}

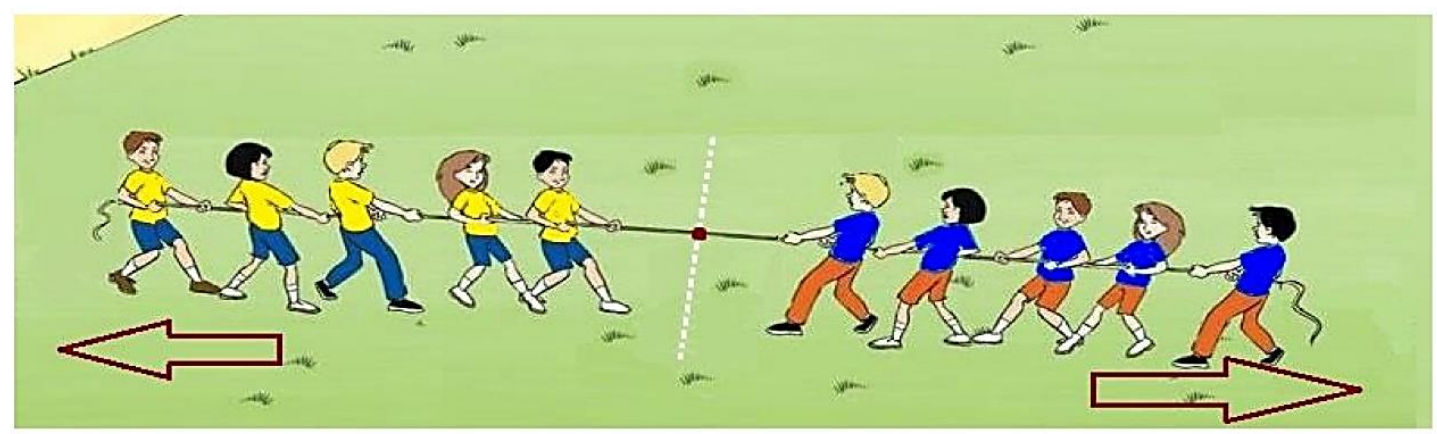

Halat çekme oyununu duymuşsunuzdur. Hatta belki de oyunu oynayanınız bile olmuştur. Peki sizce mavi ve sarı takımlardan hangisi oyunu kazanır? Tahminlerinizi yazınız.

\section{GÖZLEM:}

MALZEMELER

* Sabit makara

*Öğretmen masas1

*Eğik düzlem arabası

*Masa kıskacı

*Eşit kollu terazi kefeleri

*Ağırlıklar(2 adet $100 \mathrm{~g}, 2$ adet $200 \mathrm{~g}$ )

*Ip

\section{DENEYIN YAPILISI}

Masa kıskaçları ile sabit makaraları masanın karşılıklı kenarlarına sabitleyiniz. Eğik düzlem arabasını masanın ortasına yerleştiriniz. İki eşit parça ip kullanarak, iplerin bir ucuna terazi kefelerini bağlayınız. İplerin diğer uçlarını da eğik düzlem arabasına bağlayınız. (NOT: Kefelerin her ikiside yerden eşit yükseklikte olmalıdır.) Kefelerin her ikisine önce $100 g^{\prime} l 1 k$ kütleleri yerleştiriniz. Gözleminizi yapınız ve sonuçları kaydediniz. Daha sonra kefelerin birine $100 \mathrm{~g}$, diğerine $200 \mathrm{~g}^{\prime} \mathbf{l k}$ kütleleri yerleştiriniz. Gözleminizi yapınız ve sonuçları kaydediniz.

\section{AÇIKLAMA:}

Tahmin bölümünde cevapladığınız kazanan takımla ilgili sonuçlarınızı yaptığınız deneylerle karşılaştırarak aradaki ilişkiyi gerekçelerle açıklayınız. 


\section{Öğretmenin öğrencilere günlük hayattan örnekler vermesiyle konu pekiştirilir.}
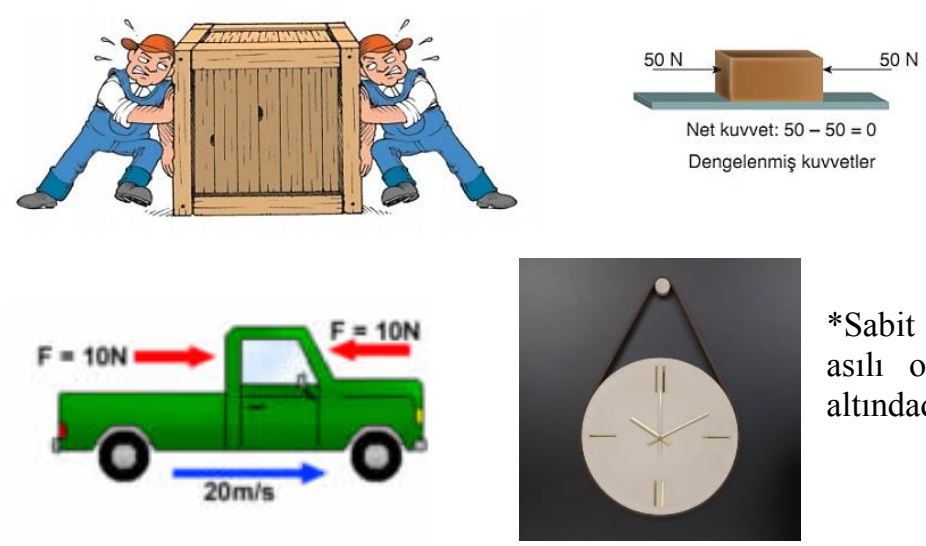

*Sabit süratle hareket eden kamyon veya duvarda asılı olan saat dengelenmiş kuvvetlerin etkisi altındadır.

Öğrencilerden, bu kuvvetlerle ilgili günlük hayattan örnekler vermeleri istenerek, dengelenmemiş kuvvetlere geçilir.

\section{Dengelenmemiş Kuvvetler}

Bir cisme uygulanan kuvvetlerin bileşkesinin büyüklüğü sıfırdan büyük ise, cisim dengelenmemiş kuvvetlerin etkisindedir. Bu durumda cismin hareketi değişir ve cisim, büyüklüğü fazla olan kuvvetin yönünde hareket eder.
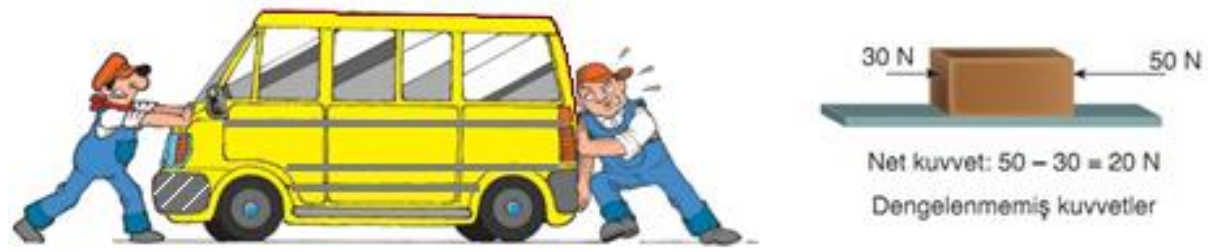

- $\quad$ Cismin dengelenmemiş kuvvetlerin etkisinde olması durumunda, bileşke kuvvetin büyüklüğü her zaman sıfırdan büyük olur.

- Durmakta olan bir cisme dengelenmemiş kuvvetlerin etki etmesi sonucunda cisim, hareket etmeye başlar.

- $\quad$ Cismin dengelenmemiş kuvvetlerin etkisinde olması durumunda, cismin hareket yönü büyüklüğü fazla olan kuvvetin yönündedir.
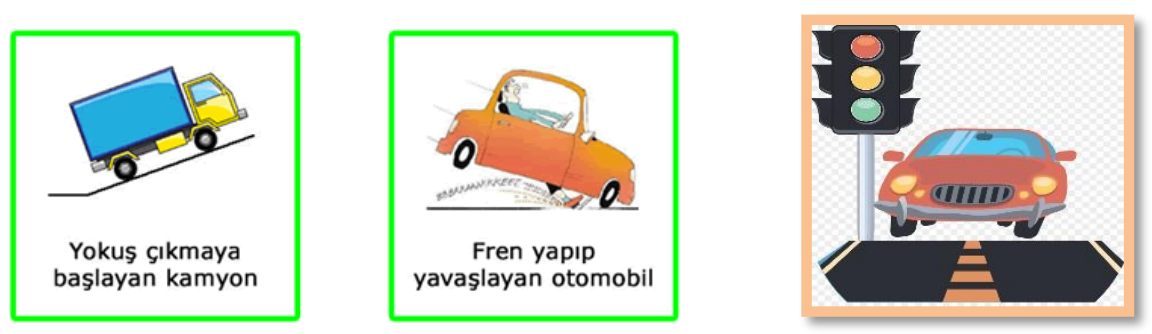

Dengelenmemiş kuvvetlerin etkisindeki cisimler; duruyorsa hareket edebilir, hareketli ise sürati artabilir veya azalabilir. Yani dengelenmemiş kuvvetler, cismin süratinde değişikliğe sebep olur.

Bu bölümde aşağıda yer alan çalışma yaprağı öğrencilerle sınıfta uygulanır. 


\section{Nasıl Dengeleriz?}

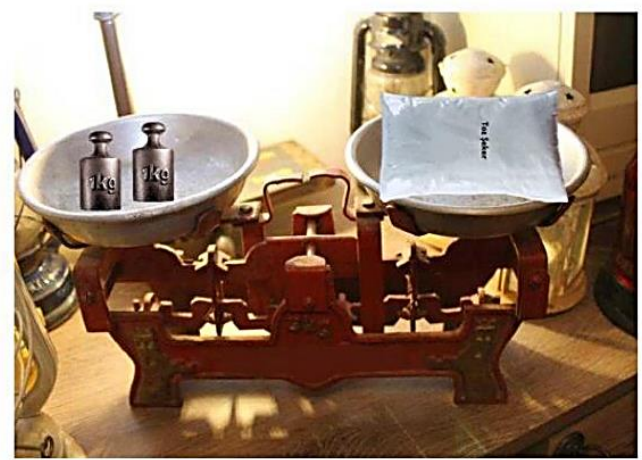

6.sınıf ögrencisi olan Ahmet babasıyla birlikte büyük babasının yaşadığı köye ilk defa gitmiştir. Büyükbabası Ahmet'ten köyün bakkalına gidip 2 kilo şeker almasını istemiştir. Bakkala giden Ahmet, bakkal amcanın şekeri tartarken kullandığı aleti hayretle inceledi. Hayatında ilk defa böyle bir araçla karşılaşmıştı. Eve gittiğinde babasına durumu anlattı. Babası da o aletin terazi olduğunu ancak son zamanlarda elektrikle çalışan terazilerin daha çok kullanıldığını anlattı. Ancak Ahmet'in kafası hala karışıktı. Bu terazinin nasıl ölçüm yaptığını çok merak etti ve kendi kendine "Acaba bu terazi elektrik kullanmadan nasıl çalışıyor?" diye düşündü.

Ahmet' in merağını gidermesine ve sorusuna cevap bulmasına yardımcı olalım.

\section{Araç - Gereçler}

* Dinamometre

* Kaldıraç kolu

* Üç ayak

* Bağlama parçası

* Destek çubuğu

\section{Deneyin Uygulanması (Grup deneyi)}

* Destek çubuğunu üç ayağa sabitleyiniz.

* Bağlanma parçasını kullanarak kaldıraç kolunu destek çubuğuna sabitleyiniz.

* Dinamometrelerin her birine bir kişi tarafindan aşağı yönde kuvvet uygulayını.

* Kaldıraç kolununu yere paralel olması durumunda dinamometrelerde okunan değerleri gözlemleyiniz.

* Farklı kuvvetler uygulayarak denge durumunu gözlemleyiniz.

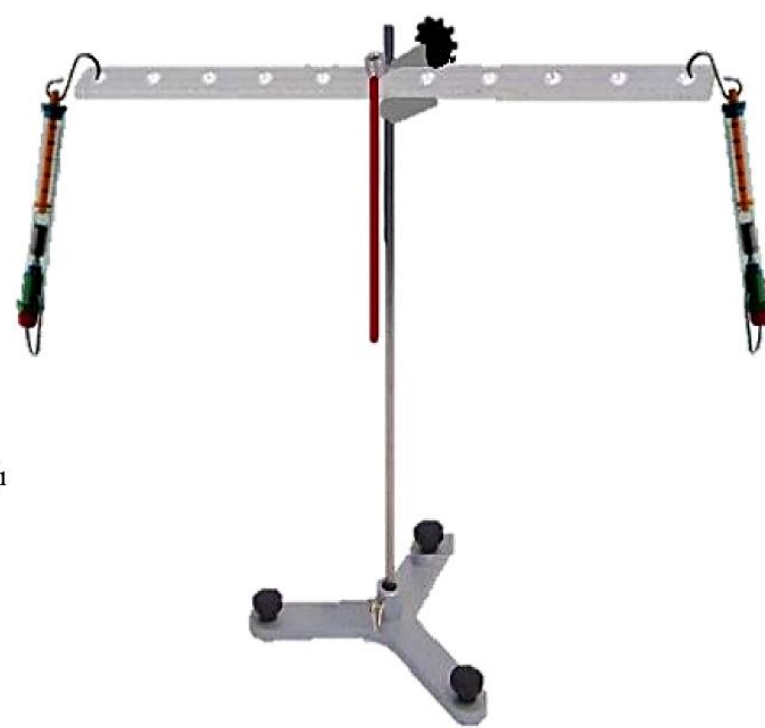

Aşağıdaki soruları cevaplandıralım.

1. Kaldıraç kolunun yere paralel olduğu durumda

dinamometrelerden okunan değerler arasında nasıl bir ilişki var?

2. Eşit büyüklükte kuvvetler ile yaptığınız deneyde kaldıraç kolunun durumu nasıl değişti?

3. Farklı büyüklükte kuvvetler ile yaptığınız deneyde kaldıraç kolunun durumu nasıl değişti? 
Çalışma yaprağında istenilenler sınıfta öğrencilere yaptırılır ve 3. bölümdeki ölçme değerlendirme çalışmasıyla uygulama tamamlanır.

Daha sonra konunun özetlenmesi amacıyla aşağıdaki bilgi haritası ve kavram haritası kullanılarak, konu pekiştirilmiş ve öğrenilenler tekrar edilmiş olur.

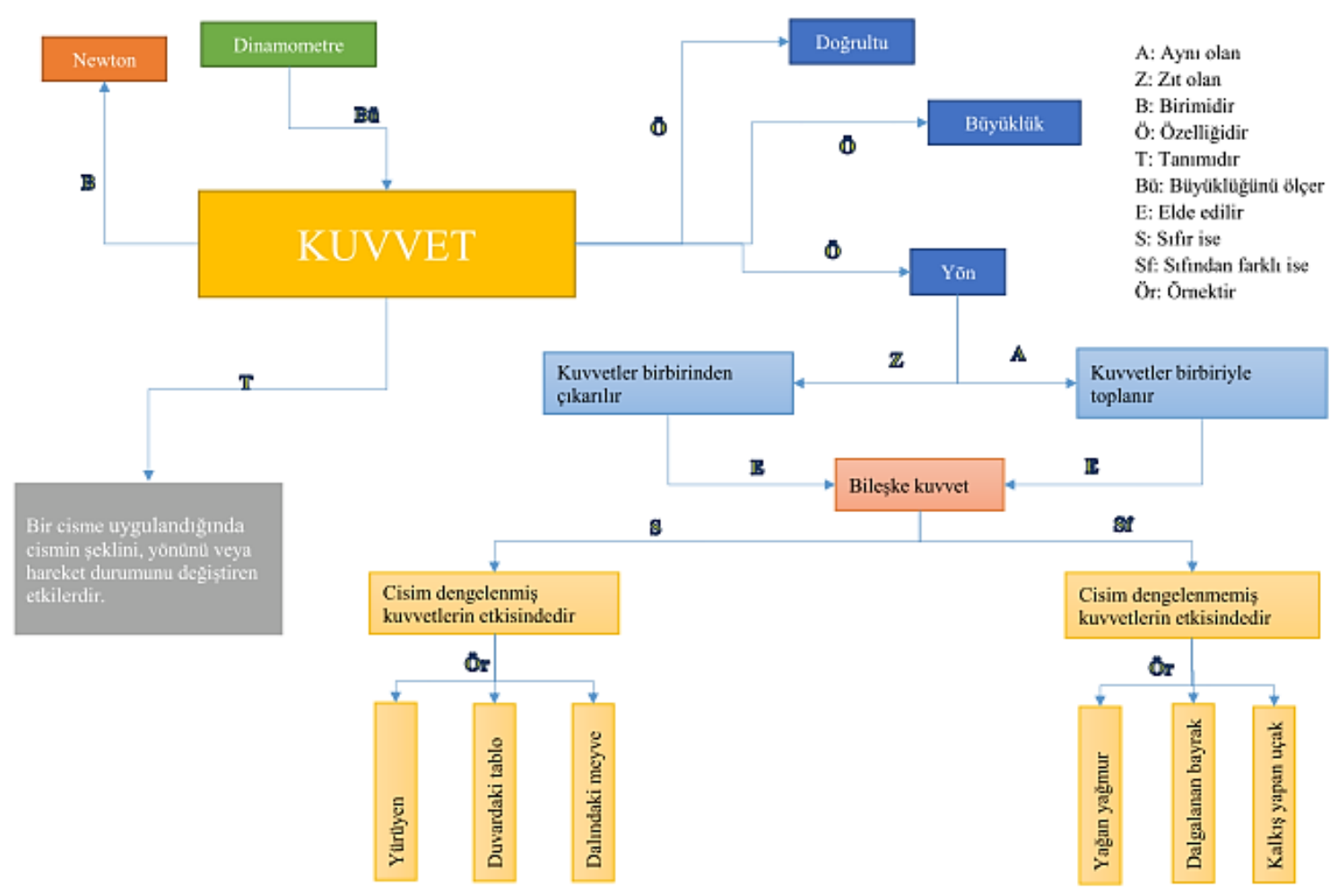




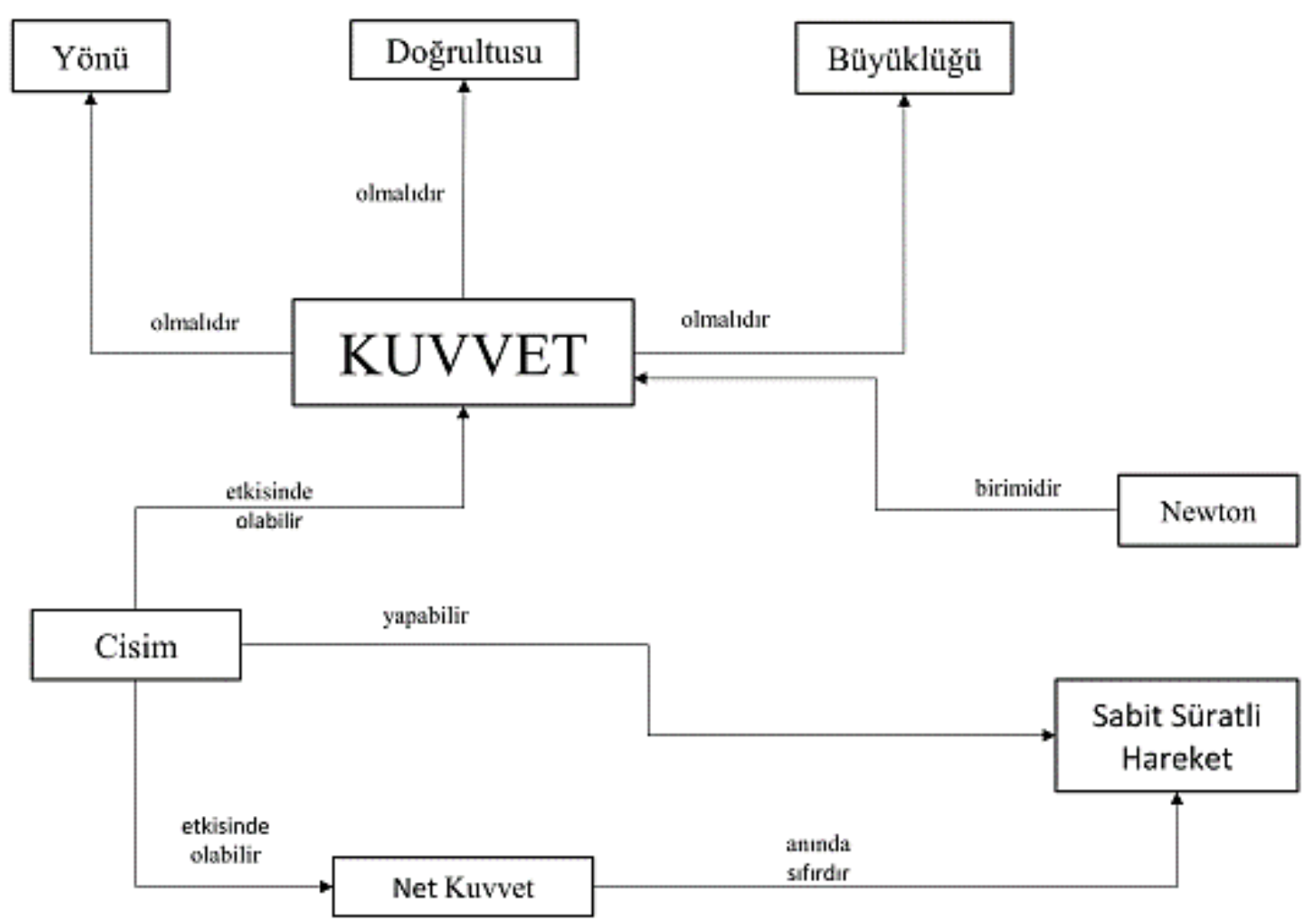

Yukarıdaki materyaller ile konu özetlendikten sonra aşağıdaki anlam çözümleme tablosu ve yapılandırılmış grid ölçme ve değerlendirme amacıyla kullanılır.

\begin{tabular}{|c|c|c|}
\hline 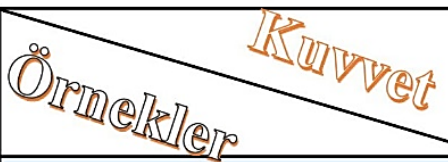 & I)engelenmis; & Dengelenmemis \\
\hline Çatıdan düşen kiremit & & \\
\hline Masada duran bardak & & \\
\hline Sabit süratle giden araba & & \\
\hline Yağan yağmur damlaları & & \\
\hline Firlatılan taş & & \\
\hline Kitaplıktaki kitaplar & & \\
\hline Duvara sabitlenmiş pano & - & \\
\hline Sabit süratle uçan uçak & & \\
\hline
\end{tabular}




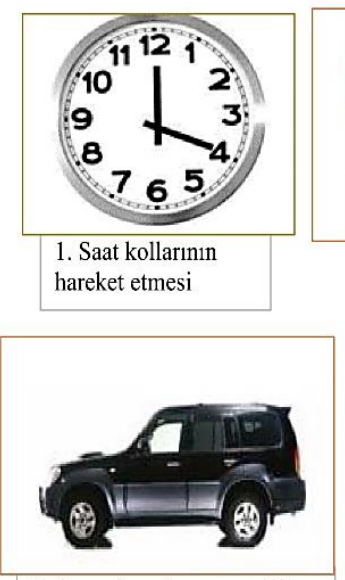

5. Durmakta olan otomobil

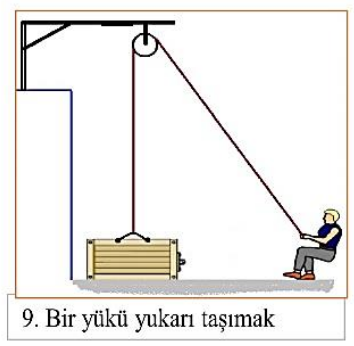

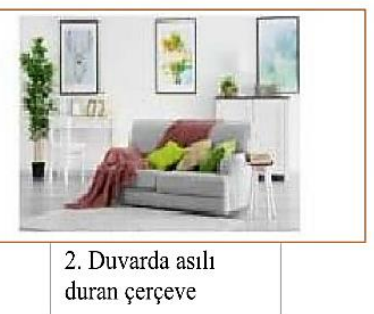
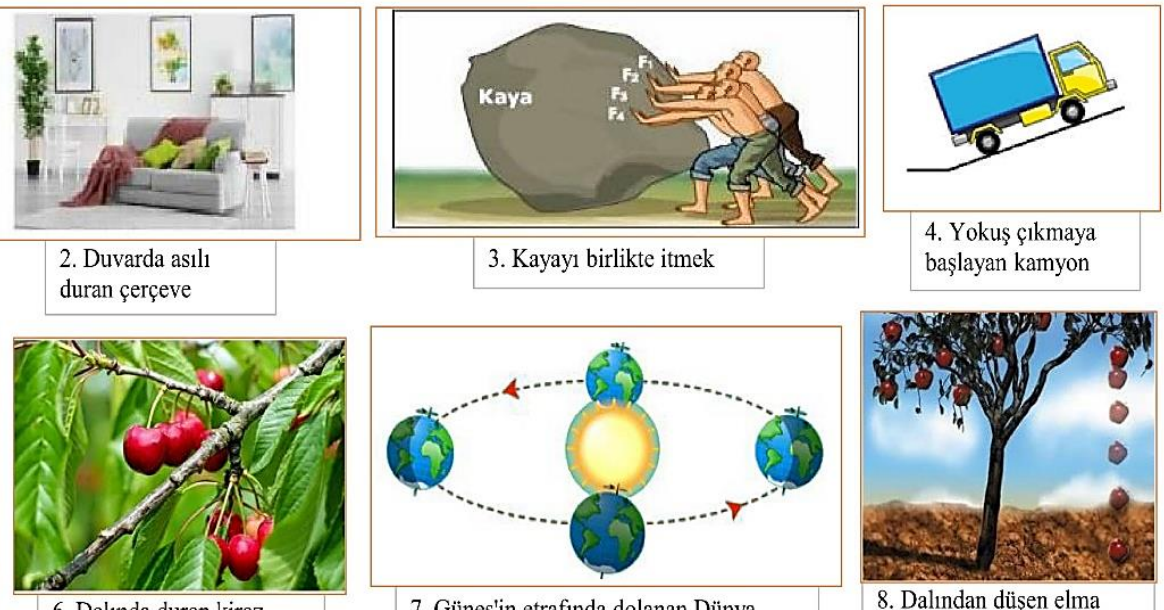

6. Dalında duran kiraz

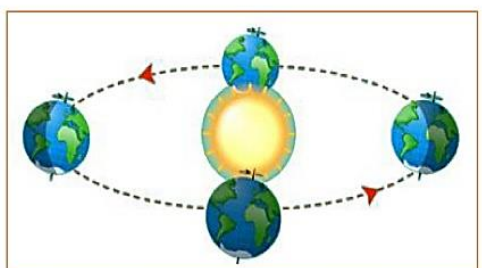

7. Güneş'in etrafinda dolanan Dünya
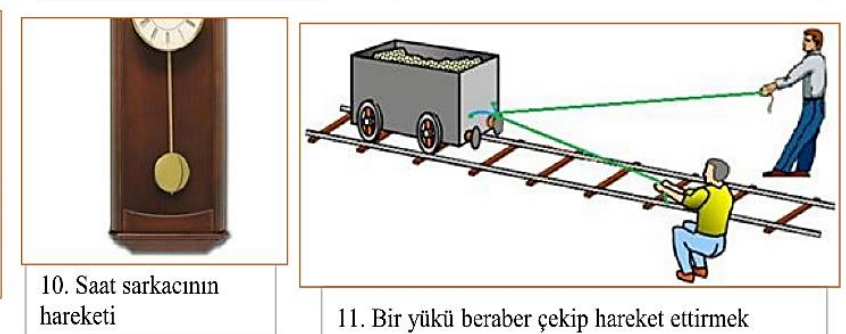

11. Bir yükü beraber çekip hareket ettirmek

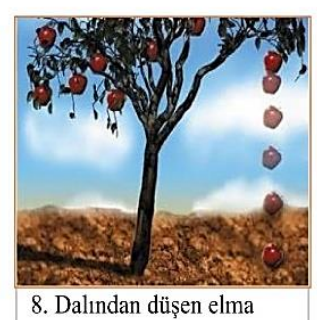

8. Dalından düşen elma

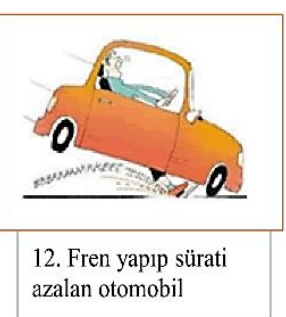

1. Yukarıda verilenlerden hangisi veya hangileri dengelenmiş kuvvetlere örnektir?

2. Yukarıda verilenlerden hangisi veya hangileri dengelenmemiş kuvvetlere örnektir?

3. Yukarıda verilenlerden hangisi veya hangileri sabit süratli harekete örnektir?

$1,2,5,6,7,10$

4. Yukarıda verilenlerden hangisinde veya hangilerinde bileșke kuvvetler etkili olmuştur?

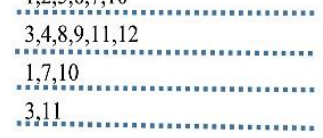

Tablo 3. Öğretim Tasarımı -3

\begin{tabular}{|c|c|}
\hline Dersin adı & Fen Bilimleri \\
\hline Sinıf & 6 \\
\hline Ünitenin Adı & Kuvvet ve Hareket \\
\hline Konu & F.6.3.2. Sabit Süratli Hareket \\
\hline Önerilen Süre & 4+2 Ders Saati \\
\hline Öğrenci Kazanımları & $\begin{array}{l}\text { "F.6.3.2.1. Sürati tanımlar ve birimini ifade eder." } \\
\text { "F.6.3.2.2. Yol, zaman ve sürat arasindaki ilişkiyi grafik üzerinde gösterir." }\end{array}$ \\
\hline $\begin{array}{l}\text { Ünite Kavramları } \\
\text { Sembolleri/Davranış } \\
\text { Örüntüsü }\end{array}$ & $\begin{array}{l}\text { "Yol, zaman, sürat ve birimleri, sabit süratli hareketin yol-zaman ve sürat- } \\
\text { zaman grafikleri" }\end{array}$ \\
\hline
\end{tabular}

\begin{tabular}{|c|c|}
\hline Açıklamalar & $\begin{array}{l}\text { "a. Sürat birimleri olarak metre/saniye } \\
\text { (m/sn.) ve kilometre/saat (km/sa) dikkate alınır." } \\
\text { " } b \text {. Yer değistirme ve hiz kavramlarına girilmez." } \\
\text { "c. Matematiksel bağıntılara girilmez." } \\
\text { "c. Birim dönüstürme vapttrllmaz." }\end{array}$ \\
\hline
\end{tabular}

Sabit Süratli Hareket

Bu bölümde aşağıda yer alan kavram ağı oluşturulup öğrencilere konuyla ilgili bilgi verilir. 


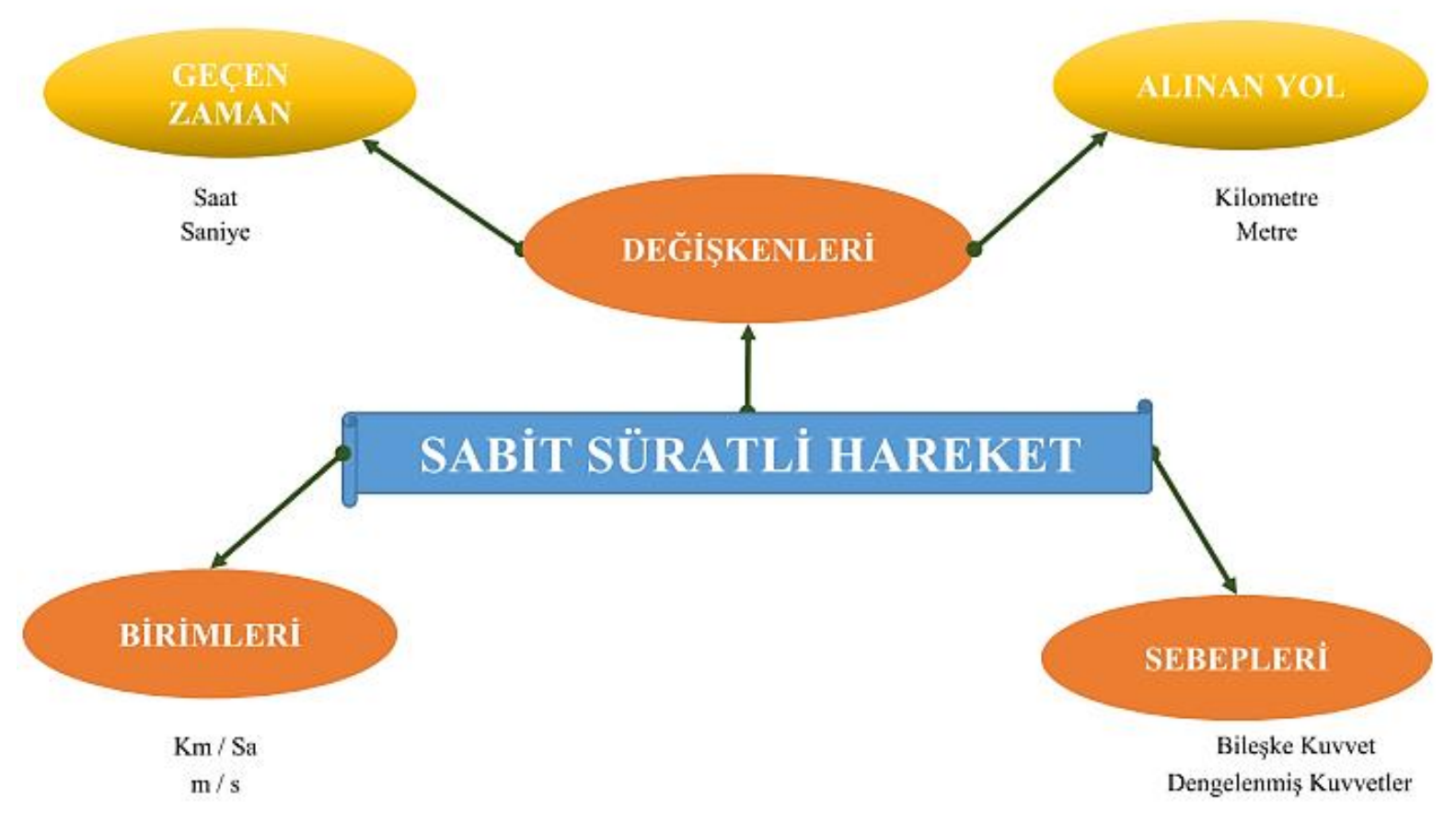

Bir cismin birim zamanda aldığı yol, sürat olarak tanımlanır.

Sürat doğrudan ölçülemez. Sürati hesaplarken alınan yol ve geçen zaman değerlerine ihtiyaç vardır. Dolayısıyla süratin birimi hem alınan yol hem de geçen zaman birimleriyle ilişsilidir.

Alınan yol: metre $(\mathrm{m})$ ya da kilometre $(\mathrm{km})$

Geçen zaman: saniye(s) ya da saat (h) (*Saat (sa) veya (h) şeklinde yazılabilir) olabilir.

Bu bağlamda sürat birimi de metre/saniye $(\mathrm{m} / \mathrm{s})$ veya kilometre/saat $(\mathrm{km} / \mathrm{sa})$ olur.

$$
\text { Sürat }=\frac{\text { Alınan yol }}{\text { Geçen zaman }}
$$

* İki araçtan, aynı yolu daha kısa sürede giden aracın sürati daha fazladır.

** İki araçtan, aynı sürede daha fazla yol giden aracın sürati daha fazladır.

*** Bir hareketli eşit zaman aralıklarında eşit uzunlukta yol alıyorsa, sabit süratli hareket yapmaktadır. Hareket süresince, hareketlinin sürati değişmez.

Bu bölümde aşağıdaki zihin haritası kullanılarak, sürat kavramının günlük yaşantıdaki yeriyle ilgili öğrencilerin dikkati çekilir. 


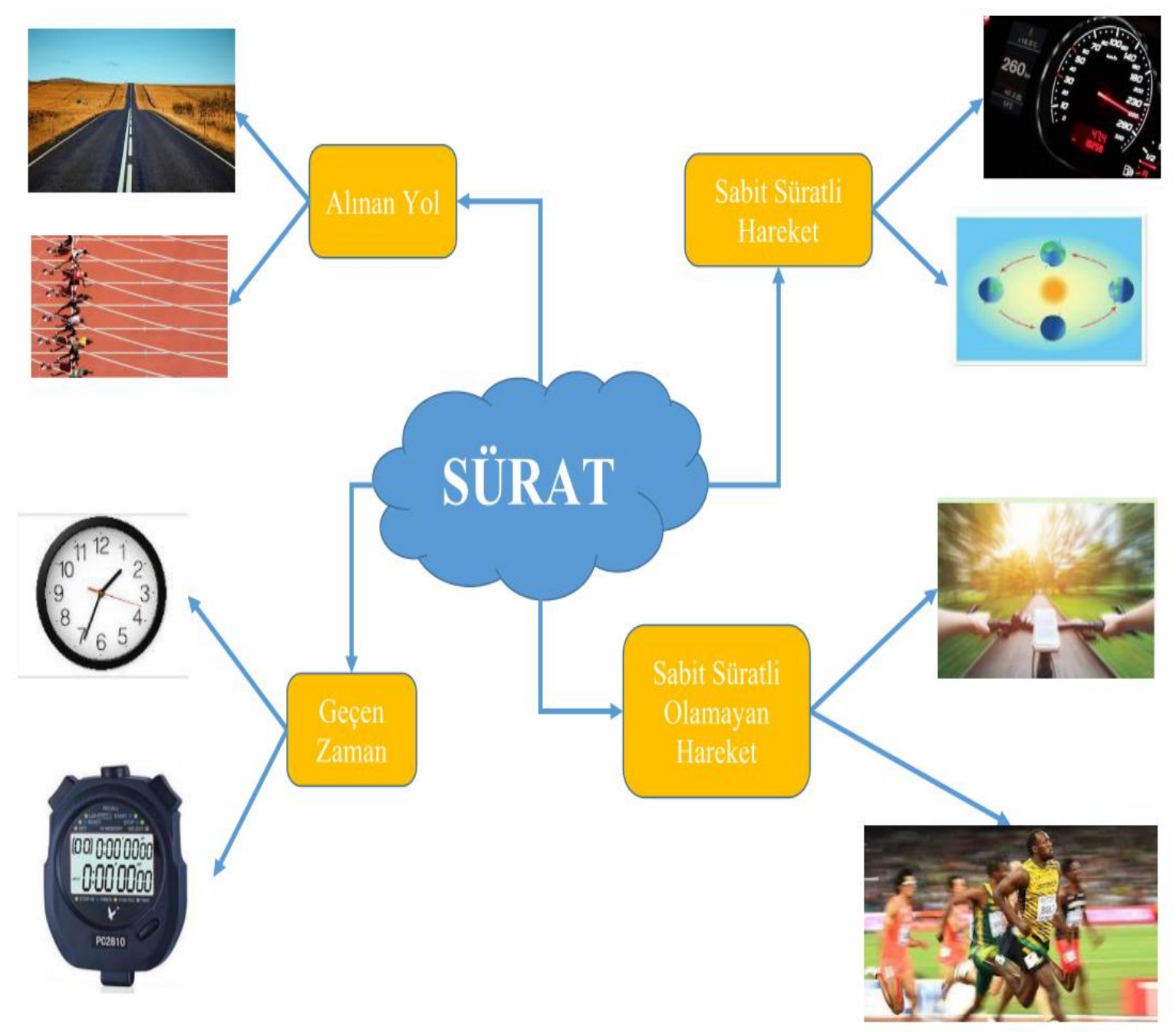

Bu bölümde aşağıda yer alan analoji yardımıyla sabit süratli hareket günlük yaşantı ile ilişkilendirilir. 


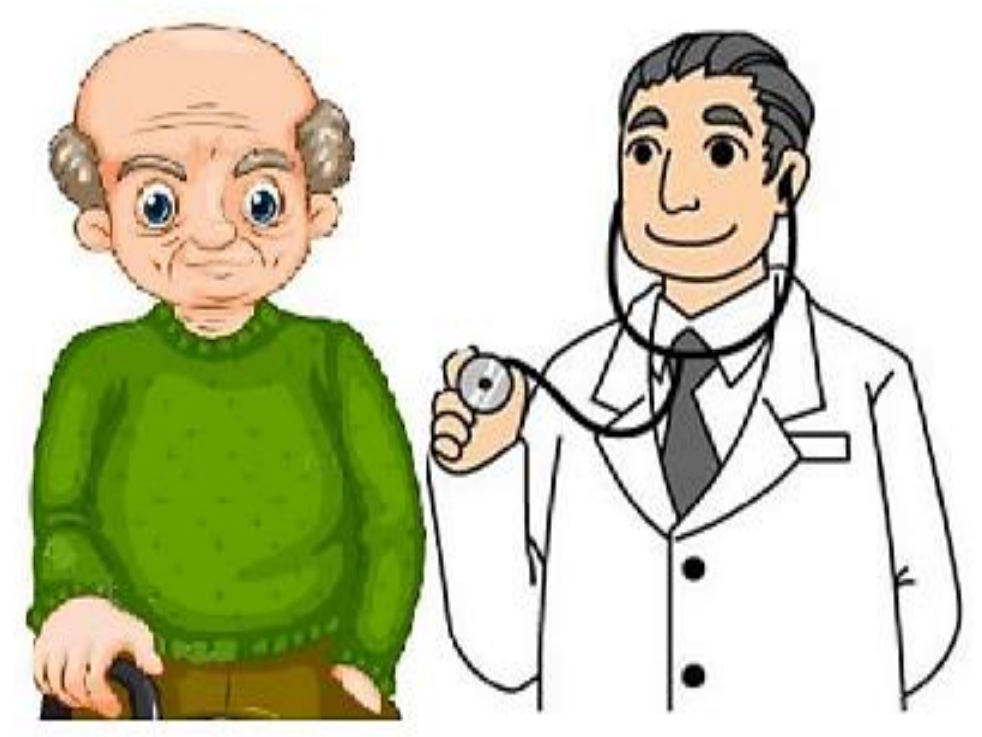

Sabit süratli harcketi daha iyi anlayabilmek için hikaycyi okuyalım.

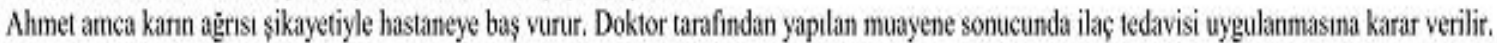

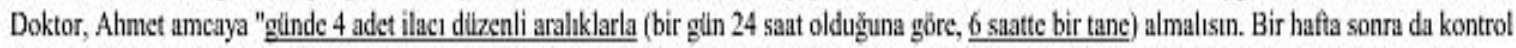
muayenesi için tekrar gel." demiş̧tit. Ahmet amca ilacm mahallesindeki eczaneden alı ve doktonunun belirttig̨ şekilde guñnde 4 adet ve düzenli. aralıklarla kullannaya başlar. Bu şekilde düzenli aralıklarla bir hafta boyunca ilacın kullanır. Geçen bir haftanun sonunda doktorunun belirttigi gibi

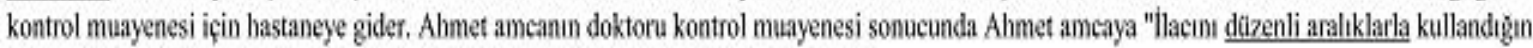
için hastallğgn iyileșmiş, geçmiş olsun" deniş ve Ahmet amcayı odasından uğurlamış.

Bu hikayede Ahmet amcann 6 saatte I adet ilaç kullanması yani belirli zaman aralklarnda belirli miktar ilą̧ kullanması, sabit süratli harckete yani belirli zaman arallkkarnda belirli miktarda yol alnumasma benzetilebilir.

\section{Grafikler}

Sabit süratle hareket etmekte olan herhangi bir cismin aldığı yol ve geçen zaman grafikle gösterilebilir. Bu grafik ile cismin sürati hakkında bilgi edinilir ve yorum yapılabilir.

Grafik çiziminde takip edilmesi gereken aşamalar aşağıda verilmiştir.

1-Aralarında $90^{\circ}$ açı yapacak şekilde kesişen biri kuzey (dikey) diğeri doğu (yatay) yönlü iki ışın çizilir.

2-Çizilen bu ışınlar, yol- zaman grafiği oluşturulmak isteniyorsa dikey olanı alınan yol, yatay olanı da geçen zaman olarak; sürat - zaman grafiği oluşturulmak isteniyorsa dikey olanı sürat, yatay olanı geçen zaman olarak adlandırılır. İsimlerin yanına parantez içinde söz konusu kavramın birimi de yazılmalıdır.

3-Yol - zaman veya sürat zaman tablosundaki değerler, isimlendirilen ışınlara kesişim noktasından (0) başlanarak sirasiyla yazilır.

4-Tablodaki alınan yol değerine denk gelen geçen zaman değerleri, grafikte kesikli veya düz çizgiler çizilerek, çizgilerin kesişim noktası işaretlenir.

5-Çizgilerin kesişim noktaları bir doğru şeklinde birleştirilir.

Etkinlik: Sürati ölçelim, grafikte gösterelim!

Kullanılan malzemeler: Kronometre, deney arabası, tebeşir-beyaz tahta kalemi, şerit metre 


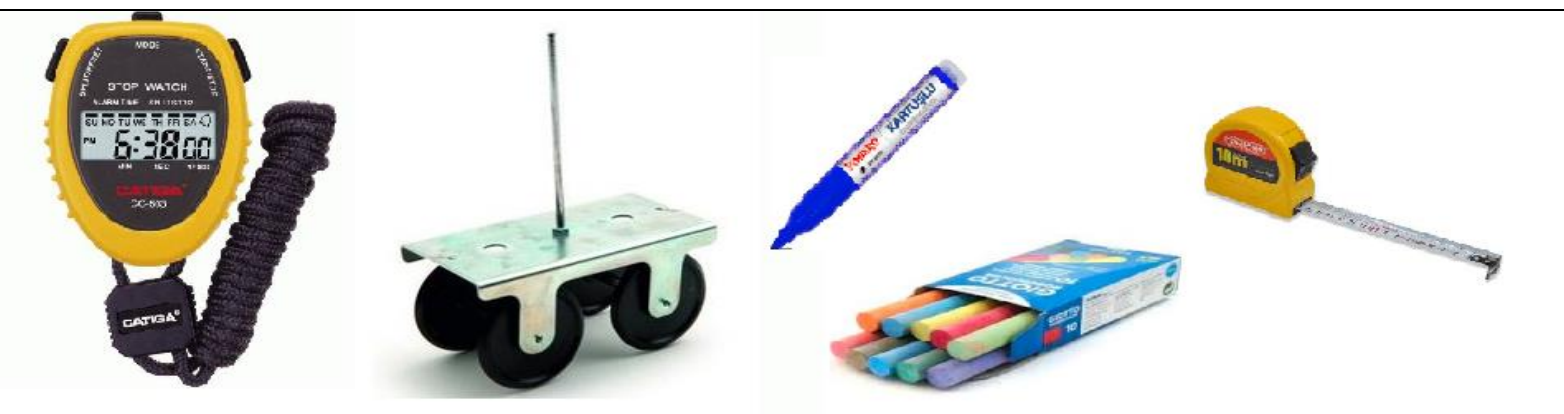

Deneyin yapılışı

Okulda temiz ve sürtünmesi az olan bir zemin belirleyelim. Şerit metre kullanarak aralarında 2 metre mesafe olacak şekilde 4 nokta belirleyelim. Deney arabasını işaretlediğimiz noktalardan geçecek şekilde kuvvet uygulayarak hareket ettirelim. Deney arabasının işaretli noktalardan geçtiği süreleri aşağıdaki tabloya not edelim.

\begin{tabular}{|l|l|l|l|l|}
\hline Alınan yol (m) & 0 & 2 & 4 & 6 \\
\hline Geçen zaman (sn) & 0 & 1 & 2 & 3 \\
\hline
\end{tabular}

Tablodaki verileri kullanarak yol - zaman grafiğini oluşturalım.

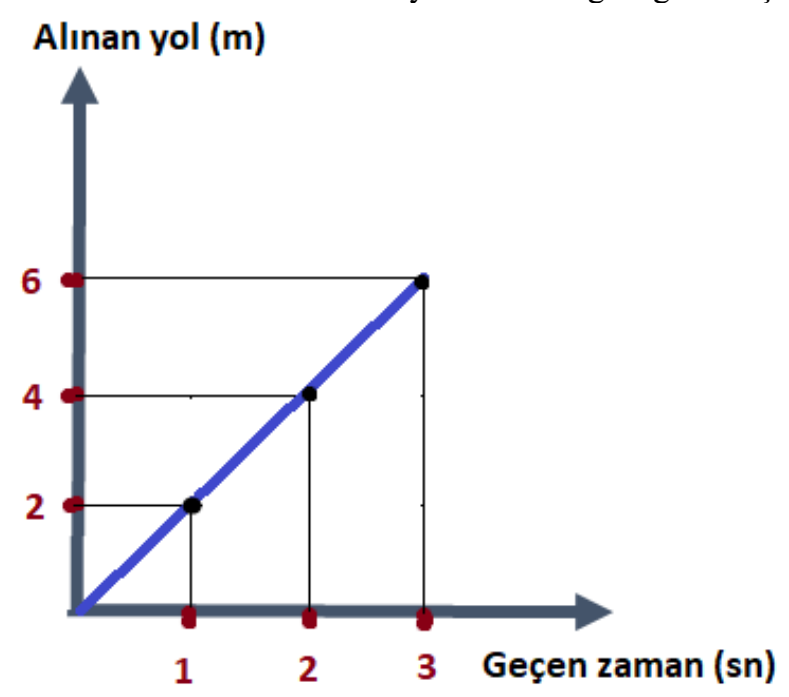

Tablodaki verileri kullanarak arabanın süratini hesaplayalım.

1.saniyedeki sürati:

\begin{tabular}{|c|c|}
\hline Sürat $=\stackrel{\text { Alınan yol }}{=}$ & $2 \mathrm{~m}$ \\
\hline Geçen zama & $1 \mathrm{~s}$ \\
\hline
\end{tabular}

2. saniyedeki sürati:

\begin{tabular}{|c|c|}
\hline Sürat $=\frac{\text { Alınan yol }}{\text { Gecen zaman }}$ & $\frac{4 \mathrm{~m}}{2 \mathrm{~s}}=2 \mathrm{~m} / \mathrm{s}$ \\
\hline
\end{tabular}

3.saniyedeki sürat:

Sürat $=\underset{\text { Geçen zaman }}{\stackrel{\text { Alınan yol }}{3 \mathrm{~s}}=2 \mathrm{~m} / \mathrm{s}}$


Geçen zaman aralıklarındaki süratler incelendiğinde bütün zaman aralıklarında sürat $2 \mathrm{~m} / \mathrm{s}$ 'dir. Bu durumda hareketli, sabit süratli hareket yapmaktadır.

\begin{tabular}{|l|l|l|l|l|}
\hline Sürat (m/s) & 0 & 2 & 2 & 2 \\
\hline Zaman (s) & 0 & 1 & 2 & 3 \\
\hline
\end{tabular}

Tablodaki verileri kullanarak arabanın sürat - zaman grafiğini oluşturalım.

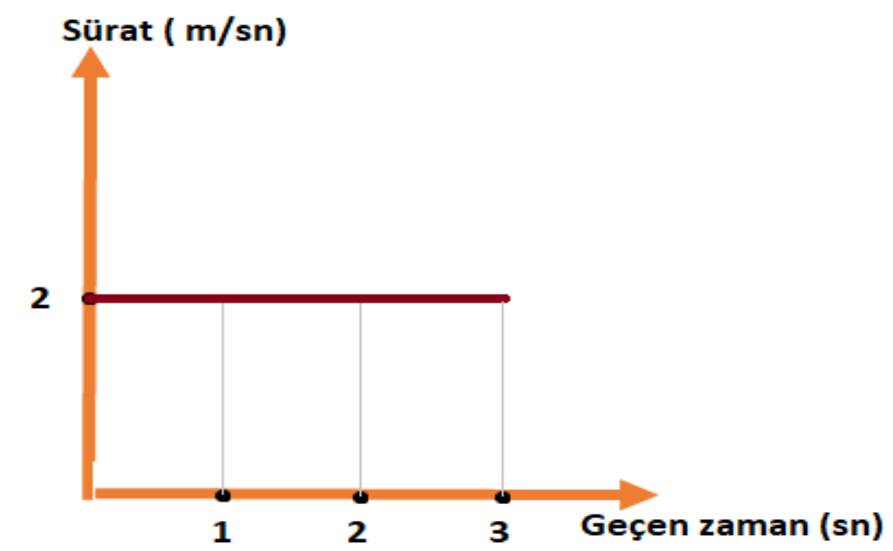

Konu sonunda ölçme ve değerlendirme amacıyla aşağıdaki tanılayıcı dallanmış ağaç kullanılabilir. 


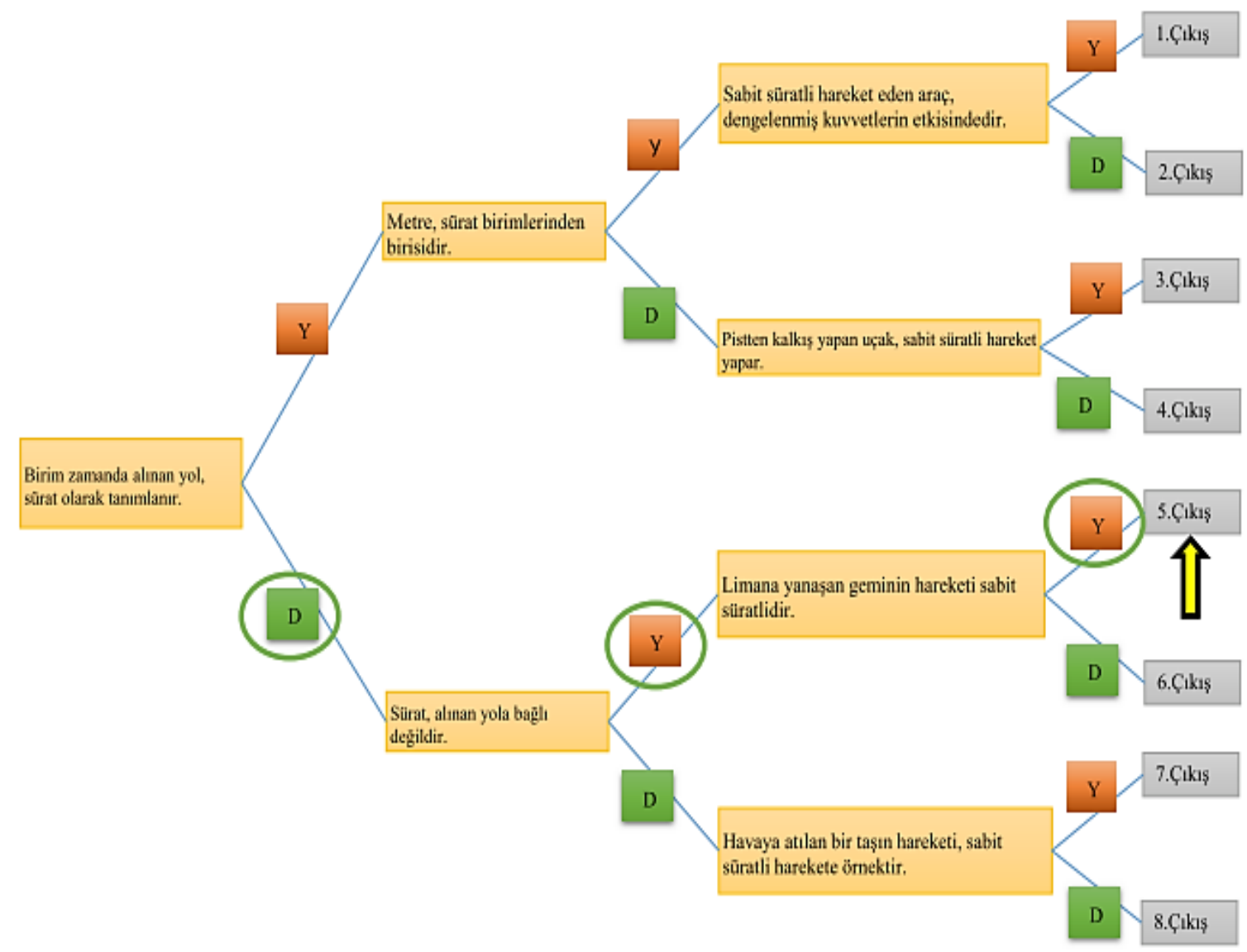




\section{TARTIŞMA, SONUÇ VE ÖNERILER}

Bu çalışmada 6. sınıf fen bilimleri öğretim programında yer alan "Kuvvet ve Hareket" ünitesine yönelik öğretmen rehber materyali geliştirilmesi amaçlanmıştır. Söz konusu rehber materyal; kavram haritası, kavram ağı, kavram karikatürü, kavram değişim metni, anlam çözümleme tablosu, zihin haritası, bilgi haritası, analoji, V-diyagramı, tanılayıcı dallanmış ağaç, yapılandırılmış grid ve çalışma yaprağını içeren bir öğretim tasarımı niteliğindedir.

Fen bilimleri dersi, yalnız bilişsel kazanımları değil, psikomotor ve duyuşsal becerileri, yaşam becerileri, bilimsel süreç becerileri, tasarım becerileri, girişimcilik becerilerinin kazandırılmasına yönelik kazanımları da içerir (MEB, 2018). Bu bağlamda geliştirilen rehber materyalin, kavramları ilişkilendirme, kavram yanılgılarını giderme ve kavram öğretimi açısından etkili olabileceği söylenebilir.

Materyal geliştirme işleminin uzmanlık gerektirdiği düşünüldüğünde, öğretmenlerin materyal geliştirebilmeleri için alanlarıyla ilgili iyi düzeyde bilgi sahibi olmaları gerekmektedir. $\mathrm{Bu}$ bağlamda alan uzmanlarınca hazırlanmış olan söz konusu rehber materyalin, öğretmenler için hem "Kuvvet ve Hareket" ünitesinin sunumunda yararlanabilecekleri bir kaynak hem de farklı konularla ilgili materyal hazırlamada örnek alabilecekleri bir doküman olması bakımından önemlidir. Buradan hareketle alan uzmanlarınca farklı konularda rehber materyallerin hazırlanması ve bu materyallerin yer aldığı öğretmen kılavuz veya öğrenci çalışma kitabı halinde elektronik veya basılı olarak yetkili merciler tarafından öğretmenlerin kullanımına sunulması önerilebilir. Ayrıca materyal hazırlama konusunda yetkili kurumlar tarafından hizmet içi eğitimlerin verilmesi sağlanabilir.

Her ne kadar geliştirilen rehber materyalin sınıf ortamında uygulaması gerçekleştirilmemiş olsa da fen bilimleri öğretmenlerinin öğrenci merkezli öğretim yaklaşımının temel mantığını algılamalarına katkı sağlayacağı düşünülmektedir. Aynı zamanda bu rehber materyalin kavram öğretiminde etkili olacağı düşünülürse, sınıf mevcudunun fazla olduğu sınıflarda tüm sınıfla materyaller üzerinden öğretim gerçekleştirilebilmesi mümkün olmayabilir. Bu bağlamda sınıf mevcutlarının azaltılmasının; kazanımlar için öngörülen sürenin gözden geçirilmesi ve kazanımların sadeleştirilmesi gerekebilir. Bunun yanında söz konusu rehber materyalin sınıf ortamında uygulanması ve etkililiğinin belirlenmesi önerilmektedir.

Geliştirilen rehber materyal 6. sınıf "Kuvvet ve Hareket" ünitesi kapsamında üç öğretim tasarımı şeklinde oluşturulmuştur. Bu tasarımlarda kavram öğretiminde kullanılabilecek farklı yöntem ve teknikler ile materyaller kullanılmıştır. Dikkat çekmek, güdülemek, motive etmek, öğrencilerin ön bilgilerini, kavramları ilişkilendirebilme ve farklı düşünebilme becerilerini ortaya çıkarmak amacıyla zihin haritalarından yararlanılmıştır. Zihin haritaları, fikir veya ilişki haritaları olarak da isimlendirilen, merkezde yer alan bir resim ile konuya odaklanıldığı, konuya ilişkin temaların merkezden çıkan dallar ile bağlandığı, dalların ise bağlantı çizgilerinin üzerindeki resim veya temel kavramları içerdiği bir görsel araçtır (Mueller, Johnston, Bligh \& Wilkinson, 2002; Şen \& Oktay, 2018). Evrekli ve Balım (2010) yapmış oldukları bir çalışmada öğrencilerin ön bilgilerini ve görüşlerini ortaya çıkarmak, sınıfta tartışma ortamı oluşturmak, öğrencilerin kavramları birbiriyle ilişkilendirebilmelerine katkı sağlamak amacıyla zihin haritalarından yararlanmıştır.

Dersin başında ve sonunda öğrencilerde var olan kavram yanılgılarını belirlemek amacıyla kavram haritaları kullanılmıştır. Kavram haritaları, kavramların birbiriyle ilişkilendirilmesinde 
öğrencilere yardımcı olacak şekilde tasarlanmış şematik gösterimler olarak tanımlanmaktadır (Davies, 2011). Bunun yanında, kavram haritalarının bilgileri şekillendirmede ve öğrencilerin kavram yanılgılarını belirlemede etkili bir öğretim tekniği olarak kullanılabildiği ifade edilmektedir (Atasoy, 2004; Novak \& Gowin, 1984). Ogundare, Bello, Adeoye ve Abimbola (2020) yapmış oldukları bir çalışmada kavram yanılgılarının giderilmesinde kavram haritalarının etkili olduğu sonucuna varmıştır.

Ders sürecinde TGA tekniği, çalışma yaprakları, kavram karikatürleri, kavram değişim metinleri ve analojilerden yararlanılmıştır. TGA fen eğitiminde öğrencilerin aktif, öğretmenin rehber olduğu etkili bir öğretim yöntemidir (Özyılmaz Akamca \& Hamurcu, 2009). TGA yönteminde öğrenciler bir tahminde bulunarak ön bilgilerini harekete geçirirler, bu tahminle çelişebilecek bir gözlemde bulunurlar ve tahminleriyle gözlemlerini karşılaştırarak anlayışlarını gözden geçirirken bir açıklama oluştururlar (James, Zo Kreager, \& LaDue, 2021). Çalışma yaprakları, kavramların öğretilmesinde öğretmenlerin başvurduğu etkili yöntemlerden biridir. Öğretim sürecinde farklı amaçlarla kullanılabilen çalışma yaprakları, farklı şekillerde tanımlanabilmekte olup kullanıcının ihtiyaçları doğrultusunda da farklı biçimlerde düzenlenebilmektedir (Ceyhan \& Türnüklü, 2002). Çalışma yaprakları, eğitim-öğretimin her basamağında kullanılabilen, konularla ilgili hedef davranışların gerçekleştirilmesinde yardımcı açıklamalara yer verilen, ders içinde veya ders dışındaki etkinliklerde kullanılabilen, aktif öğrenme sağlayan (Gödek, Polat \& Kaya, 2019), başarılması gereken temel yeterliliklere atıfta bulunan, öğrencilerin yapması gereken öğrenme görevlerinin uygulanmasına ilişkin içeriği, özetleri ve talimatları içeren (Prastowo, 2011) öğretim materyalleri olarak tanımlanmaktadır. Metinler ve görsel öğelerin birlikte yer alması yönüyle karikatürlere benzeyen kavram karikatürleri, bir soruna ilişkin biri doğru ifade, diğerleri ise yanlış ifadeler şeklinde sunulan, öğrenenleri ilgili sorunu tartışarak doğruya ulaştırmayı hedefleyen görsel araçlardır (İnel Ekici, 2016; Keogh \& Naylor, 1999). Öğrencilerde var olan kavram yanılgılarının giderilmesi ve yeni yanılgıların oluşmasının engellenmesinde yararlanılan kavram değişim metinleri, bilimsel kavramları yaygın olarak kabul edilen kavram yanılgılarıyla doğrudan karşılaştıran alternatif bir metin formatı (Hynd \& Alvermann, 1986) olup, öğrenenlerin, mevcut kavramlarından rahatsızlık hissetmelerine neden olmakta ve böylelikle sorunlara ilişkin olarak kendilerine sunulan daha tatmin edici açıklamaları kabul etmelerine imkân sunmaktadır (İnel Ekici, 2016). Kavramların ortak özelliklerinden yararlanılarak bilinmeyen bir kavramın, bilinen bir kavram yardımıyla ifade edilmesinde kullanılan analojiler, iyi bilinen bir konudaki nedensel ilişkilere atıfta bulunarak bilinmeyen bir konuda anlayış geliştirmek amacıyla (Brown \& Clement, 1989), soyut kavramların somutlaştırılmasında yararlanılan ve fen öğretiminde sıklıkla kullanılan güçlü bir teknik olarak bilinmektedir (Gödek, Polat \& Kaya, 2019). Bilen ve Köse (2012) yapmış oldukları bir çalışmada TGA stratejisine dayalı etkinliklerin sınıf öğretmeni adaylarının hem kavramsal başarılarına anlamlı bir etkisi olduğu hem de kavram yanılgılarını gidermede etkili olduğu sonucuna varmıştır. Turgut, Çolak ve Salar (2017) çalışma yaprakları geliştirdikleri bir çalışmada, çalışma yapraklarının öğrencilerin kavramsal gelişimlerine katkısı olduğu sonucuna ulaşmıştır. Chong, Salleh ve AiCheong (2013) yapmış oldukları bir çalışmanın sonucunda geliştirdikleri çalışma yaprağının, öğrencilerin kavram yanılgılarının belirlenmesinde ve giderilmesinde etkili olduğu belirtilmiştir. Yolcu (2013) kavram karikatürleri üzerine yapmış olduğu bir çalışmada kavram karikatürlerinin öğrencilerin akademik başarıları, mantıksal düşünme becerileri ve fen dersine yönelik tutumları üzerinde olumlu etkisi olduğu sonucuna varmıştır. Duran Uzun ve Koparan (2020) kavram değişim metinlerinin öğrencilerin akademik başarı ve derse yönelik tutumları üzerinde, kavram yanılgılarının giderilmesinde olumlu yönde etkisi olduğu sonucuna varmıştır. Özyılmaz Akamca ve Hamurcu (2009) tarafından yapılmış bir çalışmanın sonuçlarında analojiler, kavram 
karikatürleri ve TGA teknikleriyle desteklenmiş fen öğretiminin öğrencilerin akademik başarısı, fen dersine yönelik tutumları ve bilgilerin kalıcılığı üzerinde olumlu etkisi olduğu belirtilmiştir. Lee ve Law (2001) tarafından yapılan bir çalışmada öğrencilerde alternatif düşünme ve kavramsal değişimin sağlanmasında TGA etkinliklerinin etkili olduğu sonucuna varılmıştır. Hanson ve Seheri-Jele (2018) çalıșmalarından birinde kavram haritaları ve analoji kullanımının kavramsal değişim üzerinde etkili olduğu sonucuna varmıştır.

Dersin sonunda bilgi haritaları ve kavram ağları kullanılmıştır. Bilgi haritaları bir konudaki sözel bilgilerin ve bu bilgiler arasındaki bağlantıların çerçeve-bağ-çerçeve şeklinde biçimlendirildiği görsel öğretim araçları olarak tanımlanmaktadır. Hücre veya çerçeve olarak adlandırılan bölümde, metinde geçen temel kavramlar, kavramlara ait özellikler veya örnekler yer alırken, bağ olarak adlandırılan ve çerçeveler arasına çizilen oklara ise temsil ettikleri ilişkinin sözel etiketi yazılır (Karamustafaoğlu, 2003; Su \& Wang, 2010). Alanyazında semantik ağ olarak da isimlendirilen kavram ağı, kavram adları ve özelliklerinin birbiriyle olan ilişkilerine yer verildiği bir görsel araç olarak bilinmektedir (Solomon, Medaglia \& ThompsonSchill 2019). Kavram ağları bilgilerin özetlenmesi, konu tekrarı, eksik bilgileri ve kavramsal yanlışları belirleme amacıyla kullanılabilmektedir. Ayrıca derste kısa bir sürede hazırlanabilmesinden dolayı zaman açısından tasarruf sağlar (Şen \& Oktay, 2018). Tok (2003) bilgi haritalarını konu edindiği bir çalışmasında bilgi haritaları destekli öğretim stratejisinin ögrencilerin akademik başarıları, bilgi ve kavrama düzeyleri üzerinde olumlu etkisi olduğu sonucuna varmıştır. Su ve Wang (2010) çalışmalarının birinde ilkokul öğretmenlerinin eğitimsel değerlendirmelerinde yararlanabilecekleri bilgi haritaları tabanlı bir değerlendirme sistemi geliştirmiştir. Gürlek ve Demirkuş (2020) botanikle ilişkili kavramları kavram ağları, anlam çözümleme tabloları ve kavram haritaları ile örneklendirip sundukları bir çalışma gerçekleştirmiştir. Solomon, Medaglia ve Thompson-Schill (2019) yapmış oldukları bir çalışmada kavramları belirli özelliklerine göre sınıflandırarak bu özelliklerin birbiriyle ilişkisini kavram ağları kullanarak ortaya koymuştur.

Ders sürecinde öğrencilerin aktif olduğu deneyleri laboratuvar çalışmalarının rapor haline getirilmesinde V-diyagramları kullanılır. Bu çalışmada da bu amaçla kullanılmıştır. Vee haritası, Vee diyagramı ya da Vee heuristiği olarak adlandırılan V-diyagramları; fen bilimleri alanında laboratuvar araştırmalarının anlaşılma düzeyini arttırmak ve hazırlanan raporlarda öğrencilere, teorik bilgilerle uygulamaları ilişkilendirme konusunda yardımcı olması amacıyla geliştirilmiş bir görsel araçtır (Şen \& Oktay, 2018). Diyagramın en üst kısmında merkezi bir odak sorusu, sol tarafta kuramsal ve kavramsal bilgiler, V noktasında somut bir deney, çalışma veya deneyim ile sağ tarafında odak sorusu ışığında deneyin analizi ve değerlendirmesi vardır (Novak \& Gowin, 1984). Olgu Özkan (2011) yapmış olduğu bir çalışmanın sonucunda laboratuvar deney raporu olarak V-diyagramı kullanımının öğrencilerin akademik başarı, bilimsel süreç becerileri ve fen dersine yönelik tutumları üzerinde olumlu bir etkiye sahip olduğunu belirtmiştir. Passmore (1998) yapmış olduğu bir çalışmanın sonucunda laboratuvar eğitiminde anlamlı öğrenme ve kavram yanılgılarının giderilmesinde V-diyagramlarının etkili olduğunu belirtmiştir.

Derste kazandırılması gereken becerilerin ne ölçüde kazanıldığının belirlenmesi amacıyla, anlam çözümleme tablosu, tanılayıcı dallanmış ağaç, yapılandırılmış grid kullanılmıştır. Özellikle kavram, varlık, olay veya olguların birbirinden ayırt edilmesinde yararlanılan anlam çözümleme tabloları iki boyutlu bir tablo şeklinde düzenlenmiş görsel araçlardır. $\mathrm{Bu}$ boyutlardan birinde incelenecek olan kavram, olay, olgu veya varlıklar diğer boyutunda ise söz konusu incelenenlere ilişkin özellikler yer almaktadır (Nichols \& Rupley, 2004; Şaşmaz Ören, 
2016; Taylor, Mraz, Nichols, Rickelman \& Wood, 2009). Tanılayıcı dallanmış ağaç, içerisinde, doğru ve yanlış önermelerin temel bilgilerden ayrıntı içeren bilgilere doğru sıralandığı bir ağaç şeklinde düzenlenmiş alternatif bir ölçme-değerlendirme aracıdır. Bu araçlarda bir önermeye verilen cevabın bir sonraki cevapları da etkilemesi ve dallanma arttıkça önermelerin zorluk derecesinin de artması yönleriyle klasik yaklaşımın doğru-yanlış şeklindeki sorularından ayrilmaktadır (Hanson, 2019; Şaşmaz Ören, 2016). Öğrencilerin bir konudaki eksik bilgilerinin veya alternatif kavrama biçimlerinin tespit edilmesinin amaçlandığı yapılandırılmış grid, içerisine kavram, resim, sayı, formül vb. yerleştirildiği 9, 12 veya 26 kutucuktan ve altında da yerleştirilenlerle ilgili soruların yer aldığı bir alternatif ölçme-değerlendirme aracı olarak tanımlanmaktadır (Gödek, Polat \& Kaya, 2019; Johnstone, Bahar \& Hansell, 2010). Oğuz Tunç ve Tokcan (2020) yapmış oldukları bir çalışmada kavram haritası, yapılandırılmış grid, tanılayıcı dallanmış ağaç, kavram karikatürü, anlam çözümleme tablosu gibi alternatif ölçme değerlendirme araçlarıyla desteklenmiş öğretimin öğrencilerin akademik başarıları üzerinde olumlu yönde etkisi olduğu sonucuna varmıştır. Ahmad ve Jamil (2020) yapmış oldukları çalışmada yapılandırılmış grid, Prodjosantoso, Hertina ve Irwanto (2019) ise tanılayıcı dallanmış ağaç kullanarak öğrencilerin kavram yanılgılarını tespit etmiştir.

Sonuç olarak hazırlanmış olan bu öğretmen rehber materyalinin birçok kavram öğretim yöntem, teknik ve stratejisi ile zengin bir içeriğe sahip olduğu söylenebilir. $\mathrm{Bu}$ materyalin kullanılmasıyla "Kuvvet ve Hareket" ünitesinin öğretiminde, öğrencilerin derste daha aktif rol almasına ve öğrenmenin kalıcı olarak sağlanmasına katkı sağlayacağı düşünülmektedir.

\section{KAYNAKÇA}

Açık, A. (2015). 6, 7 ve 8. sınıf fen ve teknoloji ders kitaplarında fizik konularında karşılaşılan hatalar ve öneriler. Yüksek Lisans Tezi. Necmettin Erbakan Üniversitesi Eğitim Bilimleri Enstitüsü, Konya.

Ahmad,S., \& Jamil, S. (2020). Development and application of structural communication grid tests for diagnosing students' misconceptions in the subject of biology at secondary level. Journal of Contemporary Teacher Education, 4, 73-96.

Anıl, Ö., \& Küçüközer, H. (2015). Yapılandırmacı kurama dayalı 5E öğretim modeli kullanılarak aynalar konusunun öğretimi için örnek bir öğretim tasarımı. Fen Bilimleri Öğretimi Dergisi, $3(1), 1-15$.

Atasoy, B. (2004). Fen ögrrenimi ve öğretimi. Ankara: Asil yayın dağıtım.

Aydın, G., \& Balım, A. R. (2007). Fen ve teknoloji öğretiminde kullanılan kavramsal değişim stratejilerine dayalı örnek etkinlikler. Dokuz Eylül Üniversitesi Buca Eğitim Fakültesi Dergisi, $22,54-66$.

Bakırcı, H., \& Çalık, M. (2013). Adaptasyon ve doğal seçilim konusunda geliştirilen rehber materyallerin sekizinci sınıf öğrencilerinin alternatif kavramlarının giderilmesine etkisi. Eğitim ve Bilim, 38(168), 215-229.

Bani Slameh, H. N. (2017). Using the method of dominant incorrect answers with the FCI test to diagnose misconceptions held by first year college students. Physics Education, 52(1), 015006.

Bilen, K., \& Köse, S. (2012). Kavram öğretiminde etkili bir strateji TGA (tahmin et-gözle-açıkla) "Bitkilerde madde taşınımı". Mehmet Akif Ersoy Üniversitesi Eğitim Fakültesi Dergisi, 24, 21 42.

Brown, D. E., \& Clement, J. (1989). Overcoming misconceptions via analogical reasoning: Abstract transfer versus explanatory model construction. Instructional Science, 18, 237-261. 
Ceyhan, A., \& Türnüklü, E. B. (2002) Matematik öğretiminde kullanılabilecek bir materyal: Çalışma yaprakları. Çăgdaş Eğitim, 292, 37-46.

Chong, V. D., Salleh S. M., \& AiCheong, I. P. (2013). Using an activity worksheet to remediate students' alternative conceptions of metallic bonding. American International Journal of Contemporary Research, 3(11), 39-52.

Davies, M. (2011). Concept mapping, mind mapping and argument mapping: What are the differences and do they matter? High Education, 62(3), 279-301.

Duran Uzun, D., \& Koparan, T. (2020). Rasyonel sayılar konusu ile ilgili kavram yanılgılarının giderilmesinde kavramsal değişim yaklaşımının etkisinin incelenmesi. Cumhuriyet International Journal of Education, 9(4), 1267-1289. doi:10.30703/cije.714758

Ekantini, A., \& Wilujeng, I. (2018). The development of science student worksheet based on education for environmental sustainable development to enhance scientific literacy. Universal Journal of Educational Research, 6(6), 1339-1347. doi:10.13189/ujer.2018.060625

Er Nas, S., \& Çepni, S. (2016). Rehber materyallerin öğrencilerin kavramsal anlamaları üzerine etkisi: "Isının yayılma yolları" örneği. Marmara Üniversitesi Atatürk Eğitim Fakültesi Eğitim Bilimleri Dergisi, 43, 135-155.

Evrekli, E., \& Balım, A. G. (2010). Fen ve teknoloji öğretiminde zihin haritası ve kavram karikatürü kullanımının öğrencilerin akademik başarıları ve sorgulayıcı öğrenme becerileri algılarına etkisi. Batı Anadolu Ĕ̈itim Bilimleri Dergisi (BAED), 1(2), 76-98.

Gödek, Y., Polat, D., \& Kaya, V. H. (2019). Fen bilgisi ögretiminde kavram yanılgıları kavram yanılgilarının tespiti - giderilmesi ve uygulamalı örnekler. Ankara: Pegem Akademi.

Günaydın, G. (2010). 6. Sinıf ögrencilerinin kuvvet ve hareket konusundaki kavram yanılgılarının incelenmesi. Yüksek Lisans Tezi. Sakarya Üniversitesi Fen Bilimleri Enstitüsü, Sakarya.

Güney, K. K., \& Özmen, H. (2017). Üstün yetenekli öğrenciler için değişken kavramının öğretimine yönelik örnek etkinlikler. Fen Bilimleri Öğretimi Dergisi, 5(1), 43-67.

Gürlek, M., \& Demirkuş, N. (2020). Botanik kavramları öğretiminde, kavram çözümleme tabloları, kavram ağları ve kavram haritalarının uygulanması. Yüzüncü Yıl Üniversitesi Eğitim Fakültesi Dergisi, 17(1), 1391-1414. doi:10.33711/yyuefd.838442

Hanson, R. (2019). The impact of two-tier instruments on undergraduate chemistry teacher trainees: An illuminative assessment. International Journal for Infonomics (IJI), 12(4), 1920-1928.

Hanson, Y., \& Seheri-Jele, N. (2018). Assessing conceptual change instruction accompanied with concept maps and analogies: A case of acid-base strengths. Journal of Turkish Science Education, 15(4), 55-64. doi:10.12973/tused.10245a

Hynd, C. R., \& Alvermann, D. E. (1986). The role of refutation text in overcoming difficulty with science concepts. Journal of Reading, 29, 440-446.

İnel Ekici, D. (2016). Kavram öğretimi. İçinde Ş. S. Anagün \& N. Duban (Eds.). Fen bilimleri öğretimi (381-423). Ankara: Anı yayınc1lık.

James, N. M., Zo Kreager, B., \& LaDue, N. D. (2021). Predict-observe-explain activities preserve introductory geology students' self-efficacy. Journal of Geoscience Education, Published Online. doi:10.1080/10899995.2021.1906593

Johnstone, A. H., Bahar, M., \& Hansell, M. H. (2010). Structural communication grids: A valuable assessment and diagnostic tool for science teachers. Journal of Biological Education, 34(2), 87 89. doi:10.1080/00219266.2000.9655691 
Karamustafaoğlu, O. (2003). Fen bilgisi ve fizik ögretmen adaylarının kazanmaları istenen becerileri yansitabilecekleri ortamların düzenlenmesi. Doktora Tezi. Karadeniz Teknik Üniversitesi Fen Bilimleri Enstitüsü, Trabzon.

Keogh, B., \& Naylor, S. (1999). Concept cartoons, teaching and learning in science: An evaluation. International Journal of Science Education, 21(4), 431-446. doi:10.1080/095006999290642

Kesercioğlu, T., Yılmaz, H., Huyugüzel Çavaş, P., \& Çavaş, B. (2004). İlköğretim fen bilgisi öğretiminde analojilerin kullanımı: “örnek uygulamalar”. Ege Eğitim Dergisi, 5(1), 35-44.

Kinchin, I. M. (2000). Case study: Concept mapping in Biology. Journal of Biological Education, 34(2), 61-68.

Köse, S., Coştu, B., \& Keser, Ö.F. (2003). Fen konularındaki kavram yanılgılarının belirlenmesi: TGA yöntemi ve örnek etkinlikler. Pamukkale Üniversitesi Eğitim Fakültesi Dergisi, 1(13), 43-53.

Lee, Y., \& Law, N. (2001). Explorations in promoting conceptual change in electrical concepts via ontological category shift. International Journal of Science Education, 21(2), 111-149.

Leuchter, M., Saalbach, H., \& Hardy, I. (2014). Designing science learning in the first years of schooling. An intervention study with sequenced learning material on the topic of 'floating and sinking. International Journal of Science Education, 36(10), 1751-1771. doi:10.1080/09500693.2013.878482

Liu, G., \& Fang, N. (2016). Student misconceptions about force and acceleration in physics and engineering mechanics education. International Journal of Engineering Education, 32(1/A), 1929.

Milli Eğitim Bakanlığı -MEB- (2018). Fen bilimleri dersi öğretim programı. Ankara: T.C. Milli Eğitim Bakanlığı Talim ve Terbiye Kurulu Başkanlığı.

Mueller, A., Johnston, M., Bligh, D., \& Wilkinson, J. (2002). Joining mind mapping and care planning to enhance student critical thinking and achieve holistic nursing care. International Journal of Nursing Terminologies and Classifications, 13(1), 24-27. doi:10.1111/j.1744618X.2002.tb00161.x.S

Nichols, W. D., \& Rupley, W.H. (2004). Matching instructional design with vocabulary instruction. Reading Horizons: A Journal of Literacy and Language Arts, 45(1), 55-71.

Novak, J. D., \& Gowin, D. B. (1984). Learning how to learn. New York: Cambridge University Press.

Nuhoğlu, H. (2008). İlköğretim öğrencilerinin hareket ve kuvvet hakkındaki bilgilerinin değerlendirilmesi. İnönü Üniversitesi Ĕgitim Fakültesi Dergisi, 9(16), 123-140.

Ogundare, A. A., Bello, G., Adeoye, G. A., \& Abimbola, I. O. (2020). Effect of concept-mapping instructional strategy in remediating senior school students' misconceptions in ecology in Oyo, Nigeria. Nigerian Online Journal of Educational Sciences and Technology, 2(1), 1-9.

Oğuz Tunç, H., \& Tokcan, H. (2020). Alternatif ölçme değerlendirme etkinliklerinin sosyal bilgiler dersinde başarı ve kalıcılığa etkisi. Turkish Journal of Primary Education (TUJPED), 5(2), 171 182.

Olgu Özkan, D. (2011). İlkögretim 8. sinıf fen ve teknoloji dersi "Canlılar ve enerji ilişkileri” ünitesi deneylerinde V-diyagramı kullanımının öğrencilerin başarıları, bilimsel süreç becerileri ve tutumları üzerine etkisi. Yüksek Lisans Tezi. Gazi Üniversitesi Eğitim Bilimleri Enstitüsü, Ankara.

Özsevgeç, T. (2006). Kuvvet ve hareket ünitesine yönelik 5E modeline göre geliştirilen öğrenci rehber materyalinin etkililiğinin değerlendirilmesi. Türk Fen Eğitimi Dergisi, 3(2), 36-48.

Özsevgeç, T., Çepni, S., \& Bayri, N. (2007). Kalıcı kavramsal değişimde 5E modelinin etkililiği. Yeditepe Universitesi Ĕ̈itim Fakültesi Dergisi, 2(2), 36-48. 
Özyılmaz Akamca, G., \& Hamurcu, H. (2009). Analojiler, kavram karikatürleri ve tahmin-gözlemaçılama teknikleriyle desteklenmiş fen ve teknoloji eğitimi. Education Sciences, 4(4), 11861206.

Passmore, G. G. (1998). Using Vee diagrams to facilitate meaningful learning and misconception remediation in radiologic technologies laboratory education. Radiologic Science and Education, 4, 11-28.

Prastowo, A. (2011). Panduan kreatif membuat bahan ajar inovatif. Yogyakarta: DIVA Press.

Prodjosantoso, A. K., Hertina, A. M., \& Irwanto, I. (2019). The misconception diagnosis on ionic and covalent bonds concepts with three tier diagnostic test. International Journal of Instruction, 12(1), 1477-1488.

Pursitasari, I. D., Suhardi, E., \& Putikah, T. (2019). Fun science teaching materials on the energy transformation to promote students' scientific literacy. Jurnal Penelitian Dan Pembelajaran Ipa, 5(2), 155-168. doi:10.30870/jppi.v5i2.4008

Purwitaningrum, R., \& Prahmana, R. C. I. (2021). Developing instructional materials on mathematics logical thinking through the Indonesian realistic mathematics education approach. International Journal of Education and Learning, 3(1), 13-19.

Sadanand, N., \& Kess, J. (1990). Concepts in force and motion. The Physics Teacher, 28(8), 503-533.

Selga, M. C. R. (2013). Instructional materials development: A worktext in science, technology and society. LCCB Development Education Journal of Multidisciplinary Research, 2(1), 71-95.

Solomon, S. H., Medaglia, J. D., \& Thompson-Schill, S.L. (2019). Implementing a concept network model. Behavior Research Methods, 51, 1717-1736. doi:10.3758/s13428-019-01217-1

$\mathrm{Su}$, C. Y., \& Wang, T.I. (2010). Construction and analysis of educational assessments using knowledge maps with weight appraisal of concepts. Computers \& Education, 55(3), 1300-1311.

Şaşmaz Ören, F., Ormanc1, Ü., Babacan, T., Koparan, S., \& Çiçek, T. (2011). Analoji ve araştırmaya dayalı öğrenme yaklaşımı temelli rehber materyal geliştirme çalışması: "Madde ve Değişim" öğrenme alanı. Kuramsal Eğitimbilim, 4(2), 30-64.

Şaşmaz Ören, F. (2016). Fen bilimlerinde alternatif ölçme-değerlendirme. İçinde Ş. S. Anagün \& N. Duban (Eds.). Fen bilimleri öğretimi (277-340). Ankara: Anı yayıncılık.

Şaşmaz Ören, F., \& Erdem, Ş. (2014). Fen ve teknoloji dersi 'Iş1k' ünitesine yönelik rehber materyal geliştirme çalışması. Ë̆itim ve Öğretim Araştırmaları Dergisi, 3(3), 223-233.

Şen, A. İ., \& Oktay, Ö. (2018). Grafiksel gösterim yöntemleri ile fen öğretimi. İçinde O. Karamustafaoğlu, Ö. Tezel \& U. Sarı (Eds.) Güncel yaklaşım ve yöntemlerle etkinlik destekli fen ögretimi (330-355). Ankara: Pegem Akademi.

Şimşek, D., Yurtcan, M. T., \& Oktay, Ö. (2019). Fen bilgisi öğretmeni adaylarının kuvvet ve hareket konularındaki kavram yanılgıları. Erzincan Üniversitesi Eğitim Fakültesi Dergisi, 21(3), 195214.

Taylor, D. B., Mraz, M., Nichols, W. D., Rickelman, R. J., \& Wood, K. D. (2009). Using explicit instruction to promote vocabulary learning for struggling readers. Reading \& Writing Quarterly, 25, 205-220. doi:10.1080/10573560802683663

Tok, Ş. (2003). Illköğretim üçüncü sınıf hayat bilgisi dersinde, bilgi haritası ve inceleme-soru sormaokuma-bakmadan cevaplama-gözden geçirme stratejilerinin akademik başarı ve kalıcılığa etkisi. Doktora Tezi. Çukurova Üniversitesi Sosyal Bilimler Enstitüsü, Adana.

Turgut, Ü., Çolak, A., \& Salar, R. (2017). 7E öğrenme modeline uygun olarak çalışma yaprağı hazırlama (Elektromanyetizma ünitesi örneği). Bayburt Ĕgitim Fakültesi Dergisi, 12(23), 227-251. 
Ula, W. R. R., \& Mariyani, A. (2021). The development of guided inquiry based science basic concept teaching materials. Journal of Physics: Conference Series, 1842, 1-10.

Yılmazlar, M., Takunyacı, M., \& Günaydın, G. (2014). Öğretim programı değişikliği ile birlikte 6.sınıf öğrencilerinin kuvvet ve hareket konusundaki kavram yanılgıları. The Journal of Academic Social Science Studies, 24, 161-181.

Yin, Y. (2012). Using tree diagrams as an assessment tool in statistics education. Educational Assessment, 17(1), 22-49. doi:10.1080/10627197.2012.697850

Yolcu, H. (2013). Fen ögretiminde kavram karikatürleri tekniğinin yapılandırmacı öğrenme ortamında kullanılmasının ilköğretim 7. sinıf ögrencilerinin başarı, tutum ve mantıksal düşünme yeteneklerine etkisi. Yüksek Lisans Tezi. Mustafa Kemal Üniversitesi, Sosyal Bilimler Enstitüsü, Hatay.

Zeybek, Y. (2007). Sinıf öğretmenliği ögretmen adaylarının kuvvet, hareket ve ses konularında sahip oldukları kavram yanılgılarının tespiti üzerine bir araştırma. Yüksek Lisans Tezi. Gazi Üniversitesi Eğitim Bilimleri Enstitüsü, Ankara.

\section{EXTENDED ABSTRACT}

\section{Introduction}

When the Science Curriculum is examined, it is understood that many concepts and the need to associate these concepts with each other. The inability to learn these concepts and the relations between concepts correctly at the primary school level may prevent the correct learning of new concepts that will be encountered in the coming years. In this context, the opportunity to combine previously learned information with new information should be provided to students during the course process. Achieving this situation is possible with different teaching techniques to be applied during the course. From this point of view, concept teaching methods and techniques such as concept, knowledge and mind maps, concept cartoons, semantic features analysis, worksheets, prediction-observation-explanation, etc. can be used to learn the concepts correctly and to eliminate existing misconceptions.

When the relevant studies in the literature are evaluated, concept change texts, analogy, concept maps, concept cartoons, mind maps, etc. it is seen that the methods and techniques are presented to the teachers as a guide material. However, these studies were generally conducted over a single method or technique. In addition, no study in the type of guide material prepared for the 6th grade "Force and Motion" unit has been found in the literature. In addition, due to the fact that students have various misconceptions about the concepts in the "Force and Motion" unit and the subject is very related to daily life, etc.; in the teaching process of the subjects and concepts in this unit; A guide material containing concept teaching methods, techniques and tools in different parts of the course and for different purposes has been developed for the use of teachers and researchers. In this context, it is thought that this study, which aims to present many methods and techniques for the 6th grade "Force and Motion" unit as a guide material to teachers, will contribute to the elimination of this deficiency in the literature.

\section{Method}

In this study, a guide material for the 6th grade "Force and Motion" unit was developed by using several concept teaching methods and techniques. This guide material covers the 
subjects of "Net Force" and "Motion with Constant Velocity" in the "Force and Motion" unit. While creating the guide materials, the studies on the concept teaching materials in the literature were examined. Afterward, the unit and the subject were determined and some materials were prepared to be used in the course for different purposes (determining prior knowledge, summarizing, evaluating, preventing the emergence of some misconceptions, or eliminating misconceptions). In the process of creating the materials, expert opinion was used and necessary arrangements were made in line with the expert opinion. An instructional design has been developed to be a guide material that teachers can follow in gaining the achievements in the "Force and Motion" unit by using the finalized concept teaching materials, methods and techniques.

\section{Findings}

In this section, a sample instructional design that contains the concept teaching methods and techniques related to the "Force and Motion" unit and prepared as a guide for teachers is included. It is stated in the Science Curriculum that the time allocated for the achievements of the unit in question is 14 hours. In this context, a total of three instructional designs, two designed for four course hours and one designed for six course hours, were developed.

\section{Conclusion and Discussion}

The developed guide material was created as three instructional designs within the scope of the 6th grade "Force and Motion" unit. In these designs, different methods, techniques, and materials used in concept teaching were used. Mind maps were used to attract attention, motivate, reveal students' prior knowledge, associate concepts, and think differently. Concept maps were used to determine the misconceptions of the students at the beginning and end of the lesson. During the course, POE technique, worksheets, concept cartoons, concept change texts and analogies were used in the teaching process. Knowledge maps and concept networks were used at the end of the lesson. Vee diagrams were used to report the laboratory studies of the experiments in which the students were active during the course. Semantic features analysis, diagnostic branched tree and structured grid were used in order to determine to what extent the skills that should be gained in the course were acquired.

Although the developed guide material has not been implemented in the classroom environment, it is thought that it will contribute to science teachers' perception of the basic logic of the student-centered teaching approach.

\section{Kaynak Gösterimi İçin (For cited in):}

Yolcu, H., Karamustafaoğlu, S. \& Karamustafaoğlu, O. (2021). Fen bilimleri eğitiminde kavram öğretimi yöntemlerine dayalı rehber materyal tasarımı: kuvvet ve hareket. Turkish Journal of Primary Education, 6 (2), 126-156. Doi: https://doi.org/10.52797/tujped.976198 